Aus der Abteilung Prothetik

(Komm. Leiter: Dr. med. dent. N. Gersdorff)

im Zentrum Zahn-, Mund- und Kieferheilkunde

der Medizinischen Fakultät der Universität Göttingen

\title{
ETABLIERUNG EINER ZELLKULTUR VON \\ PDL-FIBROBLASTEN AUS PARODONTAL ERKRANKTEM \\ ZAHNHALTEAPPARAT DES MENSCHEN
}

INAUGURAL-DISSERTATION

zur Erlangung des Doktorgrades für Zahnheilkunde der Medizinischen Fakultät

der Georg-August-Universität zu Göttingen

vorgelegt von

Anna Maria Entorf

aus

Wittingen

Göttingen 2010 
Dekan:

I. Berichterstatter:

II. Berichterstatter/ in:

III. Berichterstatter/ in:
Prof. Dr. med. C. Frömmel

Prof. Dr. med. N. Miosge

Tag der mündlichen Prüfung: 


\section{Inhaltsverzeichnis}

Abbildungsverzeichnis VII

Tabellenverzeichnis IX

Abkürzungsverzeichnis $\quad X$

1 Einleitung 1

1.1 Das Parodontium: Bestandteile, Strukturen, Zusammensetzung 1

$\begin{array}{lll}1.2 & \text { Die Parodontitis }\end{array}$

1.2.1 Definitionen und Klassifikationen der Parodontalerkrankungen 6

1.2.2 Ätiologie und Pathogenese der chronischen Parodontitis $\quad 7$

1.2.3 Immunabwehrmechanismen des Wirts 9

1.2.4 Risikofaktoren für die Entstehung einer Parodontitis 11

$\begin{array}{lll}1.3 & \text { Stand der Literatur } & 11\end{array}$

$1.4 \quad$ Allgemeines zur Zellkultur und zu den eingesetzten Antibiotika 12

$\begin{array}{lll}1.5 & \text { Zielsetzung und Aufgabenstellung } & 15\end{array}$

2 Material und Methoden 16

$\begin{array}{lll}2.1 & \text { Probenmaterial } & 16\end{array}$

2.1.1 Patientenkollektiv und Gewebepräparation 16

$\begin{array}{lll}2.1 .2 & \text { Zellkultur } & 16\end{array}$

2.1.2.1 Kultivierung der PDL-Zellen 16

2.1.2.2 Herstellung des Kulturmediums 17

$\begin{array}{lll}\text { 2.1.2.3 } & \text { Entwicklung der spezifischen Antibiose } & 17\end{array}$

$\begin{array}{lll}\text { 2.1.2.4 Ernte der PDL-Zellen } & 20\end{array}$ 
2.1.2.5 mRNA-Isolierung aus dem PDL 21

2.1.2.6 Konzentrationsbestimmung der Gesamt-RNA und Synthese der cDNA

$2.2 \quad$ Real-time (RT)-PCR 22

2.2.1 Primerdesign 22

2.2.2 Verifizierung der Gen-Sequenzen 23

2.2.3 Durchführung der real-time (RT)-PCR 23

$2.3 \quad$ FACS-Analyse 24

2.3.1 Antikörpermarkierung 24

2.3.2 Flow-zytometrische Analyse $\quad 25$

2.3.3 Computergestützte Auswertung 25

2.3.4 Messung des Anteils der antigen-exprimierenden Zellen 25

$\begin{array}{lll}2.4 & \text { Statistische Auswertung } & 27\end{array}$

$\begin{array}{ll}3 \text { Ergebnisse } & 28\end{array}$

3.1 $\quad$ Ergebnisse der real-time (RT)-PCR 28

$\begin{array}{lll}3.1 .1 & \text { Schmelzkurvenanalyse } & 28\end{array}$

3.1.2 mRNA-Analytik: relative Quantifizierung 30

3.1.2.1 Normalisierung der real-time-Expressionsergebnisse mittels $\begin{array}{ll}\text { Beta2Mikroglobulin }(\beta 2 \mathrm{M}) & 31\end{array}$

3.1.2.2 Berechnungen der Ratio 32

$\begin{array}{lll}3.2 & \text { Ergebnisse der FACS-Analysen } & 34\end{array}$

$\begin{array}{lll}\text { 3.2.1 } & \text { Auswertung der Proben }\end{array}$

3.2.2 Ergebnisse der flow-zytometrischen Analyse der spezifischen Oberflächenantigene der Zellen und deren statistische Auswertung $\quad 34$

3.2.2.1 Auswertung der flow-zytometrischen Analyse und Statistik der Zellen aus gesundem und parodontitisch erkranktem Gewebe im Hinblick auf die Oberflächenantigene CD29 und CD44

3.2.2.2 Auswertung der flow-zytometrischen Analyse und Statistik der Zellen aus gesundem und parodontitisch erkranktem Gewebe im Hinblick auf die Oberflächenantigene CD73 und CD13 
3.2.2.3 Auswertung der intrazellulären flow-zytometrischen Analyse und Statistik der Zellen aus gesundem und parodontitisch erkranktem Gewebe im Hinblick auf Kollagen Typ I (Col I)

3.2.2.4 Auswertung der intrazellulären flow-zytometrischen Analyse und Statistik der Zellen aus gesundem und parodontitisch erkranktem Gewebe im Hinblick auf Runx2

\section{Diskussion}

4.1 Diskussion der Entwicklung der spezifischen Antibiose in der Zellkultur

4.2 Diskussion von CD13 (Aminopeptidase N) 


\section{Abbildungsverzeichnis}

Abbildung 1: $\quad$ Strukturen des Parodontiums $\quad 1$

Abbildung 2: $\quad$ Bakteriell leicht kontaminierte Zellkultur 19

$\begin{array}{lll}\text { Abbildung 3: } & \text { Bakteriell stark kontaminierte Zellkultur } & 19\end{array}$

Abbildung 4: $\quad$ Sehr konfluente Zellkultur 20

Abbildung 5: $\quad$ Morphologie der Zellen aus gesundem Parodont 20

Abbildung 6: $\quad$ Morphologie der Zellen aus parodontitisch erkranktem $\begin{array}{ll}\text { Parodont } & 20\end{array}$

Abbildung 7: $\quad$ Zellen im FSC/SSC-Dot-Plot 26

Abbildung 8: $\quad$ Darstellung der Zellen in einem FL 1/FL 2-Dot-Plot 26

Abbildung 9: $\quad$ Exemplarische Schmelzkurve eines spezifischen real-time (RT)-PCR-Produkts 28

Abbildung 10: $\quad$ Exemplarische Schmelzkurve eines spezifischen real-time (RT)-PCR-Produkts

Abbildung 11: $\quad$ Beispiel für ein Primer-Dimer bei einer Schmelzkurvenanalyse

Abbildung 12: $\quad$ Veränderungen der Expression verschiedener Gene im parodontitisch erkrankten gegenüber dem gesunden Gewebe

Abbildung 13: $\quad$ Box-Plot-Darstellung der Expression von CD29 in gesundem und parodontitisch erkranktem PDL-Gewebe

Abbildung 14: $\quad$ Box-Plot-Darstellung der Expression von CD44 in gesundem und parodontitisch erkranktem PDL-Gewebe

Abbildung 15: $\quad$ Box-Plot-Darstellung der Expression von CD73 in gesundem und parodontitisch erkranktem PDL-Gewebe

Abbildung 16: $\quad$ Box-Plot-Darstellung der Expression von CD13 in gesundem und parodontitisch erkranktem PDL-Gewebe

Abbildung 17: $\quad$ Box-Plot-Darstellung der Expression von Kollagen Typ I in gesundem und parodontitisch erkranktem PDL-Gewebe

Abbildung 18: $\quad$ Box-Plot-Darstellung der Expression von Runx2 in gesundem und parodontitisch erkranktem PDL-Gewebe 
Bildtafel 1: $\quad$ Vergleich zwischen gesundem und erkranktem Gewebe (CD29, CD44)

Bildtafel 2: $\quad$ Vergleich zwischen gesundem und erkranktem Gewebe (CD73, CD13)

Bildtafel 3: $\quad$ Vergleich zwischen gesundem und erkranktem Gewebe (Kollagen Typ I)

Bildtafel 4: $\quad$ Vergleich zwischen gesundem und erkranktem Gewebe (Runx2) 


\section{Tabellenverzeichnis}

Tabelle 1: $\quad$ Entwicklung der Konzentrationen von Amphotericin B 19

Tabelle 2: $\quad$ Entwicklung der Konzentrationen von Amoxicillin 19

Tabelle 3: Entwicklung der Konzentrationen von Metronidazol 19

Tabelle 4: $\quad$ Oligonukleotidprimer für die real-time (RT)-PCR 22

Tabelle 5: $\quad$ Pipettieransatz pro Gen und Well 23

Tabelle 6: PCR-Programm zur quantitativen Analyse der eingesetzten cDNA 24

Tabelle 7: $\quad$ Auflistung der Antikörper und deren extrazelluläre Markierung (direkt) einschließlich der Hersteller

Tabelle 8: $\quad$ Auflistung der Antikörper einschließlich der Hersteller (intrazelluläre Markierung, FITC)

Tabelle 9: Auswertung des Analyseergebnisses in tabellarischer Form 26

Tabelle 10: Darstellung der Expression in der real-time (RT)-PCR 33

Tabelle 11: Tabellarische Übersicht der prozentualen positiven Expression eines Antigens im FACS 


\section{Einleitung}

\subsection{Das Parodontium: Bestandteile, Strukturen, Zusammensetzung}

Anatomisch besteht das Parodontium aus vier Bestandteilen, hiervon sind zwei Hartgewebe (Alveolarknochen und Wurzelzement) und zwei Weichgewebe (Parodontalligament PDL und Gingiva). In einem Zahnquerschnitt mit dem dazugehörigen Alveolar- und Knochenabschnitt sind von innen nach außen folgende Strukturen erkennbar (Kleber 1998):

- Wurzelzement

- Faserapparat des Desmodonts

- Alveolarknochen

- Gingiva.

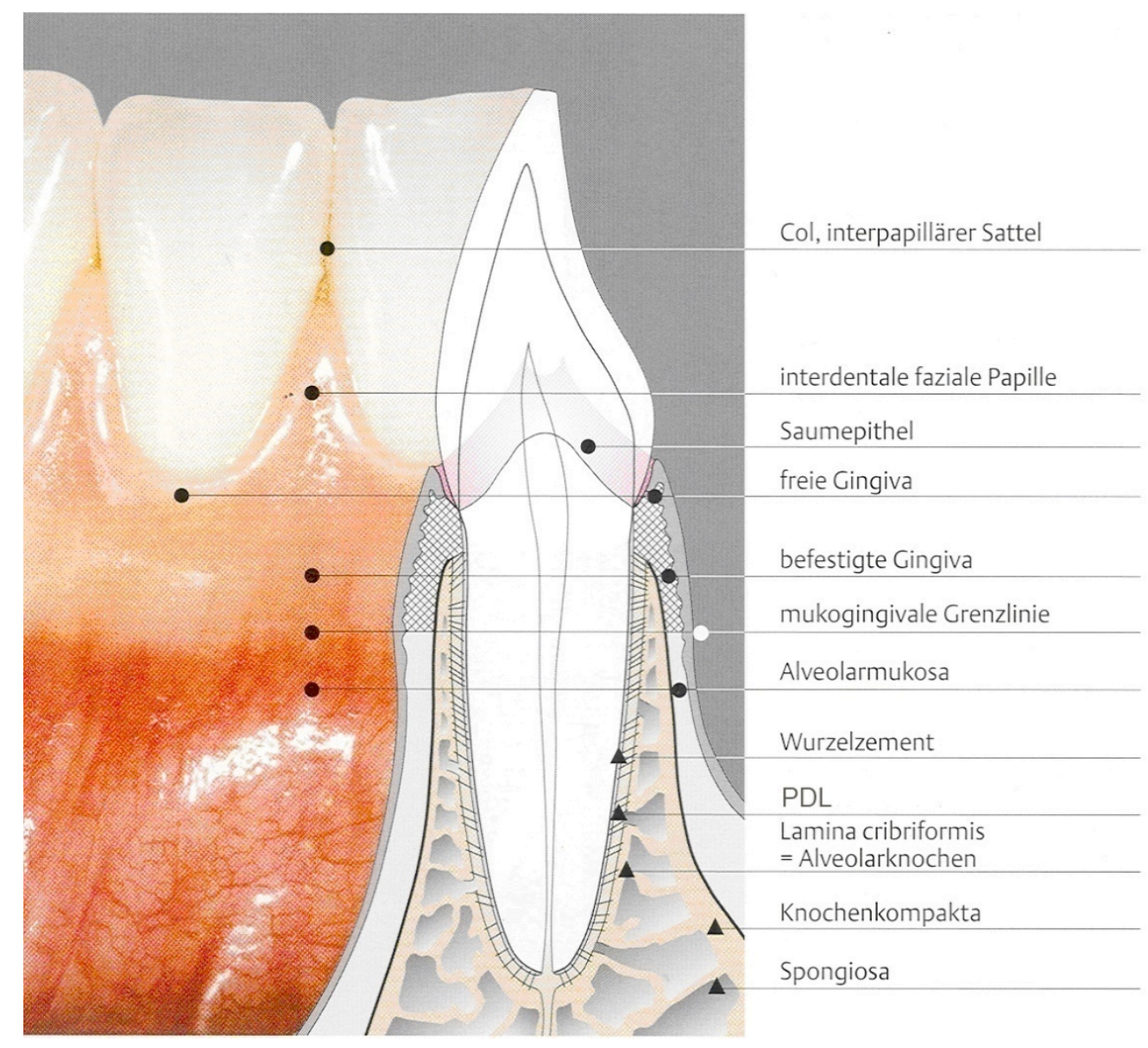

Abb.1: Strukturen des Parodontiums (entnommen aus Wolf et al., 2003, S.1), PDL steht für Parodontalligament 
$\mathrm{Zu}$ der Hauptaufgabe des Parodonts gehört u.a. die Abwehr äußerer Noxen (Schroeder 2000). Im Folgenden werden die vier Elemente des Parodontiums näher beschrieben.

\section{Die Gingiva}

Der am weitesten peripher gelegene Anteil des Parodontiums ist die Gingiva. Sie ist gleichzeitig auch ein Bestandteil der Mundschleimhaut und hält die Kontinuität der epithelialen Auskleidung der Mundhöhle mithilfe des Saumepithels aufrecht, welches den Zahnhals ringförmig umgibt (Schroeder 2000). Als Hauptstrukturen lassen sich bei der Gingiva das orale Epithel und das orale Sulkusepithel mit dem Saumepithel unterscheiden.

Das der Mundhöhle zugewandte orale Epithel ist ein mehrschichtig, geringfügig verhorntes Plattenepithel und 0,2-0,3 mm dick. Es besteht von innen nach außen aus den folgenden vier Schichten (Schroeder und Theilade 1966):

- Stratum basale

- Stratum spinosum

- Stratum granulosum

- Stratum corneum.

Die im Stratum basale lokalisierten Melanozyten versorgen die in der Umgebung liegenden Keratinozyten mit Melanin, welches die Haut vor ultraviolettem Licht schützt. Die Keratinozyten keratinisieren auf ihrem Weg durch die anderen Schichten an die Hautoberfläche und stellen so einen mechanischen Schutz der Gingiva dar. Auch das Erbgut im Nucleolus der Zelle wird dadurch vor UV-Licht geschützt (Okazaki et al. 1976). An nichtepithelialen Zellen befinden sich im oralen Epithel Langerhans-Zellen, Merkel-Zellen und kleine Lymphozyten.

In dem Binde- und Stützgewebe, welches an das Stratum basale angrenzt, befinden sich Kollagenfasern des Typs I und III (Everts et al. 1998). Makroskopisch entsteht 
durch die in die Basalmembran inserierenden Kollagenfasern eine Oberflächenstippelung der Gingiva. Die Fasern gehören zum supra- bzw. infraalveolären Faserapparat, welcher den festen Verbund zwischen Gingiva, Alveolarknochen und dem Wurzelzement gewährleistet. Hinsichtlich ihrer Verlaufsrichtung lassen sich gingivale Faserbündel weiter differenzieren in z.B. dentogingivale, alveologingivale oder transgingivale Fasern.

Klinisch ist die Oberflächenstippelung ein Zeichen für den Gesundheitszustand des Parodonts. Liegt eine Gingivitis vor, geht die Stippelung durch den Kollagenverlust verloren. Die Zellen, welche die Kollagenfasern produzieren, liegen unter dem Stratum basale im Bindegewebe. Hauptsächlich sind dies Fibroblasten, Zellen des Bindegewebes, die eine wichtige Rolle bei der Produktion der extrazellulären Matrix (EZM) spielen.

Das orale Sulkusepithel hingegen ist dem Zahn zugewandt, sein struktureller Aufbau ist jedoch mit dem des oralen Epithels identisch. Am Sulkusboden geht das orale Sulkusepithel in das Saumepithel über. Das Saumepithel ist in korono-apikaler Richtung etwa $2 \mathrm{~mm}$ hoch und dehnt sich vom Boden des gingivalen Sulkus bis zur Schmelz-Zement-Grenze aus. Das Saumepithel mit seinem Epithelansatz (einem Komplex aus Halbdesmosomen und interner Basallamina) stellt die epitheliale Haftung der Gingiva an der Zahnoberfläche sicher (Schroeder 2000).

Des Weiteren übernimmt das Saumepithel wichtige Aufgaben in der Abwehr äußerer Noxen. Neben der hohen Umsatzrate der Saumepithelzellen (Skougaard 1965) ist hierfür das periphere Immunsystem ein wichtiger Faktor. Während die Umsatzrate des oralen Gingivaepithels 8-12 Tage beträgt, ist die des Saumepithels doppelt so hoch. Exogene Noxen wie z.B. Bakterien werden somit schnell beseitigt. Polymorphkernige neutrophile Granulozyten (PMN) durchwandern zudem das Saumepithel in Richtung des gingivalen Sulkus und wirken so ebenfalls vorhandenen Noxen entgegen (Cimasoni 1983).

Der Alveolarknochen

Als Teil des Alveolarfortsatzes umfasst der Alveolarknochen die Zähne in einem knöchernen Fach (Kleber 1998). Anatomisch lassen sich beim Alveolarknochen ein 
Processus alveolaris (Maxilla) und eine Pars alveolaris (Mandibula) unterscheiden. Der Knochen besteht aus einer Spongiosa und einer Kompakta, welche röntgenologisch als Lamina dura erkennbar ist. Die zahnalveolenwandbildende Kompakta (Lamina cribriformis) ist charakterisiert durch die Volkmann- und Hartmann-Kanäle, welche die Knochenplatte durchlöchern und durch die Blutgefäße und Nerven ziehen. Im Vergleich der Kompakta von Ober- und Unterkiefer fällt die stärker ausgeprägte Kompakta des Unterkiefers auf.

Die Spongiosa setzt sich aus zarten, netzförmig angeordneten Knochenbälkchen zusammen, zwischen denen sich Knochenmarksräume befinden. Zellulär finden sich Osteoblasten, Osteoklasten und Zellen des Immunsystems, die ihre Funktion in der Anpassung und Regeneration des Knochens haben (Granstrom und Nilsson 1987). Die Alveolarfortsätze bilden sich nach Zahnverlust zurück (Inaktivitätsatrophie). Die Hauptaufgaben des Alveolarknochens sind neben der Zahnverankerung auch die Aufnahme und Verteilung der Kaukräfte, die durch Zahnkontakt während des Schluckens, Sprechens, Kauens und durch motorische dentale Fehlfunktionen wie z.B. bei Stress entstehen.

Das Wurzelzement

Das Wurzelzement ist dem Dentin aufgelagert und erstreckt sich vom gingivalen Sulkus nach apikal. Das Zement ist strukturell dem Knochen ähnlich, gehört zu den Stützgeweben des Körpers und ist aus Zementoblasten, Zementozyten, Fibroblasten und der EZM aufgebaut. Da an dem Zement die Sharpey-Fasern (Kollagenfasern des Parodontalligaments) haften, die den Zahn in der Knochenalveole beweglich aufhängen, gehört es zum Zahnhalteapparat (Berkovitz 2004).

Das Parodontalligament (PDL)

Zwischen Wurzelzement und Alveolarknochen liegt im Parodontalspalt das PDL. Diese funktionelle Einheit aus den beiden Hartgeweben und dem PDL ermöglicht eine gelenkartige Verbindung zwischen Zahn und Knochen. 
Das primär fibröse PDL-Gewebe ist hauptsächlich aus Kollagenfasern und oxytalanartigen Fasern (ca. 53-74\%) sowie Blutgefäßen, Nerven, der EZM und einer Vielzahl an Zellen zusammengesetzt, wobei die Bindegewebsfasern den Faserapparat des PDLs bilden. Unterscheiden lassen sich orientierte, vom Alveolarknochen zum Zement verlaufende Faserbündel (Sharpey-Fasern) und mehrheitlich die Gefäße und Nervenstränge umspannende, lose und nicht gebündelte Faseranteile (Schroeder 2000). Die von den Fibroblasten produzierten Kollagenfasern gehören überwiegend zum Kollagen Typ I (ca. 80\% der im PDL vorkommenden kollagenen Fasern), die übrigen $20 \%$ gehören zu den Typ-IIIKollagenen (Butler et al. 1975, Limeback und Sodek 1979). Die Aufhängung des Zahnes in seiner Alveole wird durch die Sharpey-Fasern ermöglicht. Hierfür inserieren auf einer 1- $\mathrm{mm}^{2}$ - Zementoberfläche eines in Funktion stehenden Zahnes durchschnittlich 28.000 kollagene Faserbündel. Auf der anderen Seite setzen die Sharpey-Fasern an der zum PDL gelegenen Alveolarknochenfläche an. Die hierfür vorhandene Knochenfläche ist jedoch durch die zahlreichen kleinen Foramina (Mündungen der Volkmann-Kanäle), mit denen 5-10\% der Fläche versehen sind, verkleinert (Birn 1966). Neben den Kollagenfasern synthetisieren die Fibroblasten auch die oxytalanartigen Fasern (oxytalan = säure-resistent), welche unausgereifte elastische Fasern sind, die parallel zu den Blutgefäßen und Nerven in apikokoronaler Richtung liegen. Es wird angenommen, dass diese oxytalanartigen Fasern durch Registrierung der jeweiligen Zahnstellung bei funktioneller Beanspruchung den Blutdurchfluss im PDL regulieren (Jonas und Riede 1980, Sims 1975). Die Gesamtpopulation der im PDL vorkommenden Zellen besteht aus Fibroblasten, Osteo- und Zementoprogenitorzellen, Osteoblasten und Osteoklasten, Zementoblasten und Dentoklasten, Epithelzellen und Leukozyten (Schroeder 2000), wodurch eine sehr heterogene und funktionell unterschiedliche Population entsteht. Die Fibroblasten bilden zahlenmäßig die größte Population. Charakteristisch für diese Zellen ist eine spindelförmige Gestalt mit einem länglichen, ovalen Kern und zahlreichen, unterschiedlich langen zytoplastischen Fortsätzen. Eine der Hauptaufgaben der Fibroblasten besteht in der Bildung der Grundsubstanz der EZM, in die sie eingebettet sind. Häufig lassen sie zytoplasmatische Vakuolen erkennen, die kurze, bruchstückhafte Kollagenfibrillen und proteolytische Enzyme enthalten, was darauf schließen lassen könnte, dass die Fibroblasten sowohl an der Synthese 
des Faserapparats als auch an der Resorption des von innen gebildeten Kollagens beteiligt sind (Eley und Harrison 1975, Ten Cate 1972, Ten Cate und Deporter 1974).

Die Vorläuferzellen der Zemento- bzw. Osteoblasten sind die Zemento- und Osteoprogenitorzellen, welche ausschließlich in zement- oder knochennahen Abschnitten des PDL lokalisiert sind. Diese Progenitorzellen, die den Zement und den Knochen remodellieren, treten nur unregelmäßig und in zeitlichen Intervallen auf. Im zementnahen Drittel des PDL findet man die Epithelzellen des PDL vor, bei denen es sich um Epithelreste der von Malassez beschriebenen Hertwigschen Epithelscheide aus der Zahnentwicklung handelt (Schroeder 2000), welche die Bildung der Zahnwurzel leitet (Hertwig 1874). Durch anhaltende Proliferation unter stimulierendem Einfluss akuter und chronischer Entzündungsvorgänge können diese Epithelreste Zysten bilden.

Man kann zusammenfassend festhalten, dass der Faserapparat des Parodontiums kein statisches System ist, sondern einer ständigen Erneuerung unterworfen ist. Daran sind in hohem Maße die Fibroblasten beteiligt, die sowohl für die Synthese der EZM, besonders von Kollagen Typ I, als auch für den enzymatischen Abbau des Kollagens verantwortlich sind (Melcher und Chan 1981).

\subsection{Die Parodontitis}

\subsubsection{Definitionen und Klassifikationen der Parodontalerkrankungen}

1999 wurde auf dem "International Workshop for a Classification of Periodontal Diseases and Conditions" in Oak Brook (Illinois/USA) eine neue Einteilung der verschiedenen Parodontalerkrankungen beschlossen, welche die in den letzten Jahrzehnten neu untersuchten verschiedenen Krankheitsbilder klassifiziert. Die neue Klassifikation löst die bisher gültige Nomenklatur ab (alte Klassifikation 1989 durch „Proceedings of the World Workshop in Clinical Periodontics") und orientiert sich nicht an der früheren Einteilung, welche nach dem Lebensalter des Auftretens bei der Erstdiagnose und der Progressionsrate erfolgte. Die Parodontalerkrankungen werden wie folgt klassifiziert: 


\section{Gingivale Erkrankung}

2. Chronische Parodontitis

3. Aggressive Parodontitis

4. Parodontitis als Manifestation einer Systemerkrankung

5. Nekrotisierende Parodontalerkrankung

6. Parodontalabszesse

7. Parodontitis im Zusammenhang mit endodontalen Läsionen

8. Entwicklungsbedingte oder erworbene Deformationen und Zustände.

\subsection{2 Ätiologie und Pathogenese der chronischen Parodontitis}

Laut Definition handelt es sich bei der Parodontitis um eine bakterielle Entzündung des Parodontiums, also der Gingiva, des Wurzelzements, des Alveolarknochens und des PDL (Preshaw et al. 2004, Pindborg 1987). Ein unterschiedlich ausgeprägter Verlust von Alveolarknochen, PDL und umliegendem Weichgewebe ist Folge der Parodontitis, welcher in schweren Fällen sogar zum Zahnverlust führen kann. Trotz der verschiedenen Einteilungen der Parodontitisformen, die primär auf den Ursachen und dem Verlauf der jeweiligen Parodontitis basieren, sind die klinischen Merkmale bei allen Gruppen ähnlich. Dies ist neben einer erhöhten Sondierungstiefe und Blutung nach Sondierung des Sulkus in den meisten Fällen auch noch eine im Zuge der Entzündung starke Schwellung der Gingiva. Charakteristisch für die Pathogenese der Parodontitis ist, dass ihr immer eine Gingivitis zusammen mit der Ausbildung einer Zahnfleischtasche vorausgeht, wobei es sich bei der Gingivitis jedoch um eine auf die Gingiva beschränkte Entzündung handelt. Die Ausbildung eines strukturierten Biofilms (Plaque) auf der Zahnoberfläche ist der wichtigste Faktor der Entstehung. Dieser Biofilm entsteht durch die Anheftung von grampositiven, aeroben, aus dem Speichel kommenden Mikroorganismen an die Pellikelschicht (Duan et al. 1994). Diese wiederum bildet sich innerhalb weniger Stunden auf allen Glattflächen nach gründlicher Reinigung der Zähne. Die Hauptbestandteile des Pellikels sind Speichelglykoproteine. Durch diese Erstbesiedelung (erste Phase der Plaquebildung) durch die grampositiven, aeroben Mikroorganismen ist es nun auch 
den gramnegativen Kokken sowie auch grampositiven und negativen Stäbchen möglich, die Zahnoberfläche zu besiedeln. Die Pionierkeime produzieren extrazelluläre Polysaccharide (Fruktane, Glukane), an die sich weitere Bakterien anlagern (Whittaker et al. 1996). Die Mikroorganismen können die extrazellulären Polysaccharide jedoch nur bilden, wenn sie oft mit niedermolekularen Sacchariden versorgt werden. Die Organisation der Bakterien in diesem Komplex bietet innen auch Schutz vor den immunologischen Abwehrmechanismen des Wirts (Phagozytose und Abbau durch PMN) sowie vor antibiotischen Wirkstoffen (Khoury et al. 1992). Durch die mit dem Wachstum voranschreitende subgingivale Lage des Biofilms ist die Zugänglichkeit für Mundhygienemaßnahmen erschwert, was letztendlich das Wachstum des Biofilms weiter vorantreibt. Der entzündliche Prozess der Gingiva setzt sich in tiefere Schichten fort und führt so, bleibt er unbehandelt, zur Parodontitis.

Die bakterielle Zusammensetzung des Biofilms ändert sich bei der chronischen Parodontitis von primär aeroben Kokken zu anaeroben Stäbchen und Spirochäten (Lindhe et al. 1983), da mit den tieferen Abschnitten des Parodontiums die Sauerstoffversorgung für aerobe Keime zunehmend schlechter wird. Mit der Veränderung in der Zusammensetzung des Biofilms ändert sich auch dessen Pathogenität. Die in diesem Biofilm vorhandenen (fakultativ) anaeroben Kokken, Stäbchen und Spirochäten sind erheblich pathogener als die Mikroorganismen der Gingivitis. Als besonders pathogen gelten aus der Gruppe der gramnegativen (fakultativ) anaeroben Keime vor allem Aggregatibacter actinomycetemcomitans (A.a.c), Porphyromonas gingivalis (P.g.), Tannerella forsythensis (T.f.) und Treponema denticola (T.d.). Obwohl inzwischen bekannt ist, dass parodontopathogene Erreger eine Hauptursache der Parodontitis darstellen, konnte innen nicht die alleinige Verantwortung zugeschrieben werden. Loe und Morrison konnten schon 1986 bei der Erforschung der pathophysiologischen Vorgänge beobachten, dass einige ihrer Patienten trotz Anwesenheit pathogener Keime keine Parodontitis entwickelten. Eine entscheidende Rolle spielt dem Anschein nach eine inadäquate oder übersteigerte Immunantwort des Wirts (Page et al. 1997). Auch das Modell der opportunistischen Infektion gibt wieder, dass neben einer bestimmten Qualität und Quantität der Mikroorganismen das Immunsystem des Wirtes geschwächt bzw. geschädigt sein muss, damit eine Parodontitis entstehen kann. Für den Erhalt des Zahnes ist also die Interaktion zwischen immunologischen Vorgängen 
des Wirtes und den pathogenen Mikroorganismen ausschlaggebend (Preshaw et al. 2004, Wolf et al. 2003).

\subsubsection{Immunabwehrmechanismen des Wirts}

Nachdem Page und Schroeder 1976 die histologisch-strukturbiologische Beschreibung der Gingivitis und Parodontitis dargelegt hatten, haben Kornman et al. 1997 die Gingivitis und Parodontitis neu beschrieben. Hierbei standen die neuesten molekularbiologischen und genetischen Erkenntnisse im Mittelpunkt. Kornman et al. (1997) gliederten die „erweiterte“ Pathogenese in vier Stadien:

- Reaktion des gesunden Parodontiums auf die Plaque

- Erste, akute lokale Entzündungsreaktion

- Hochregulierung der Entzündung, Infiltrat

- Chronische Immunreaktionen, Attachmentverlust.

Am Anfang des Verlaufs der vier Stadien steht die Leukodiapedese (= das Einwandern von Leukozyten aus der Blutbahn ins Gewebe). Aktiviert wird diese durch die Noxen, die von den oben beschriebenen pathogenen Bakterien der Plaque sezerniert werden (Lukic et al. 2006). Die Noxen sind kurze Fettsäuren (Butter- und Propionsäure) oder Peptide (Leukotoxine und Lipopolysaccharid (LPS)), wobei LPS als potentester Aktivator des immunologischen Entzündungsprozesses agiert (Loppnow et al. 1989, Kornman et al. 1997). Durch die verschiedenen Noxen stimuliert, sezerniert das Saumepithel Entzündungsmediatoren (Interleukin-8 (IL-8)), Tumor-Nekrose-Faktor $\alpha$ (TNF $\alpha), \quad \mathrm{IL}-1 \alpha$, Prostaglandin $\mathrm{E}_{2} \quad\left(\mathrm{PGE}_{2}\right)$ und Matrixmetalloproteinasen (MMP), welche ihrerseits die Proliferation bzw. Differenzierung von Entzündungszellen hervorrufen. Den Leukozyten wird durch eine verstärkte Sekretion von Interleukinen (IL-1 $\beta$ und IL-6) aus dem Saumepithel die Infektion signalisiert (Eckmann et al. 1994, Tonetti et al. 1993). Anhand eines Konzentrationsgradienten der an der Entzündung beteiligten Chemokine (z.B. IL-8) 
wandern die Leukozyten (vor allem neutrophile Granulozyten und Makrophagen) infolge der Leukodiapedese in das Zentrum der Infektion. Die opsonierten pathogenen Keime werden von den Leukozyten phagozytiert und durch deren verschiedene oxidierende und nicht-oxidierende Enzymsysteme abgebaut (Dennison und Van Dyke 1997). Die Opsonierung geschieht durch Immunglobuline (IgG) der Klasse IgG1 und IgG2 und durch die Komplementfaktoren C3b oder C4b.

In dem im Gewebe gebildeten entzündlichen Infiltrat überwiegen im weiteren Verlauf der chronischen Parodontitis die Lymphozyten (T- und B-Lymphozyten). Die Immunantwort des Wirts wird von aktivierten T-Lymphozyten mittels Zytokinen (IL-2, $-3,-4,-5,-6,-10,-13$, TNF $\alpha$, TGF $\alpha$, Interferon $\gamma($ INF $\gamma))$ koordiniert. Die weiter oben beschriebene Opsonierung geschieht durch aus aktivierten B-Lymphozyten entstehenden Plasmazellen, die IgG und Zytokine produzieren. Die Folge der Hochregulierung der Entzündungszellen ist ein Ablösen des Saumepithels vom Zahn. Das Saumepithel kann sich in keratinisiertes Taschenepithel umwandeln und seine ursprüngliche Position nach apikal verschieben (epitheliales Tiefenwachstum), wodurch eine gingivale Tasche entsteht. Schreitet die chronische Parodontitis weiter fort, so sind im infiltrierten Bindegewebe vermehrt aus Monozyten differenzierte Makrophagen aktiv. Die Makrophagen präsentieren den CD4-Helferzellen ( $T$ Lymphozyten) phagozytierte (bakterielle) Antigene über den MHC-II-Komplex (MHC = major histocompatibility complex). Das menschliche Immunsystem kann durch den MHC-II-Komplex (= Oberflächenprotein von humanen Zellen) körpereigene von fremden Zellen unterscheiden. Die CD4-Helferzellen regulieren die zellvermittelte Immunantwort über makrophagenaktivierende Zytokine (IL-2; IFN- $\gamma$ ) und auch über proinflammatorische Zytokine (IL-1 $\beta$, TNF- $\alpha$ ) (Gemmell et al. 1997). Durch zellspezifische Interleukine (IL-2, IL-4, IL-10, IL-12) aktivieren CD4-Helferzellen Plasmazellen zur Klonbildung, was wiederum eine erhöhte Bereitstellung spezifischer Antikörper zur Folge hat (Müller 2001, Gemmell et al. 1997).

Neben diesen Zellen und ihren Produkten finden sich auch MMPs, vor allem MMP-1 und MMP-8, durch die erstmals der kollagene Anteil des parodontalen Gewebes massiv abgebaut wird (Temeles et al. 1993, Van Heeckeren et al. 1993, Reynolds und Meikle 1997). Aktiviert durch die proinflammatorischen Zytokine bilden jetzt auch neutrophile Granulozyten und parodontale Fibroblasten, die im Gesunden die Aufgabe der Protektion (durch Kollagenproduktion) haben, EZM abbauende MMPs 
und TIMPs (tissue inhibitors of matrixmetalloproteinases) (Reynolds und Meikle 1997, Page et al. 1997). Durch die gestörte Gewebshomöostase wird das parodontale Gewebe vermehrt abgebaut. Klinische Symptome hierfür sind eine erhöhte Sondierungstiefe (Vertiefung des gingivalen Sulkus), die Entstehung einer Zahnfleischtasche und der Verlust von Alveolarknochen.

\subsubsection{Risikofaktoren für die Entstehung einer Parodontitis}

Bei den Risikofaktoren muss man zwischen primären und sekundären Risikofaktoren differenzieren. Die Zusammensetzung der Plaque und die darin enthaltenen pathogenen Keime gehören zu den primären Risikofaktoren. Kommen in der Plaque besonders viele dieser Erreger vor, ist das Risiko einer Parodontitis erhöht.

Die sekundären Risikofaktoren haben einen negativen Einfluss auf das Gewebe und die Immunität des Wirtes, wodurch dieser für eine Parodontitis empfänglicher wird. Unterscheiden lassen sich weiterhin nicht veränderbare von veränderbaren Risikofaktoren. Genetische Defekte, wie z.B. Polymorphismen in Genclustern von Zytokinen (z.B. IL-1), stellen nicht veränderbare Risikofaktoren dar. Rauchen, Stress, schlechte Mundhygiene, Ernährung, ein schlecht eingestellter Diabetes mellitus und HIV gehören z.B. zu den sekundären, veränderbaren Risikofaktoren (Meisel et al. 2007). Das Erkennen und Einordnen der Risikofaktoren spielt eine zentrale Rolle bei der individuellen Prognose und Therapiewahl.

\subsection{Stand der Literatur}

1998 arbeiteten Kuru et al. die morphologischen und funktionellen Unterschiede zwischen Fibroblasten der Gingiva und des PDL heraus (Kuru et al. 1998). In den meisten der bisher durchgeführten Studien sind PDL-Zellen gesunden Parodonts kultiviert und hinsichtlich verschiedener Eigenschaften charakterisiert worden (Zhou et al. 2008, Hirano et al. 1997, Washio et al. 2010). Auch kam in den letzten Jahren vermehrt das Bestreben auf, das PDL im Hinblick auf Stammzellen (Seo et al. 2004) und deren Eigenschaften zu untersuchen (Nagatomo et al. 2006, Gay et al. 2007, Huang et al. 2009). Lallier und Spencer untersuchten 2007 den Einfluss 
verschiedener Wachstumsfaktoren auf die Proliferation und Differenzierung auf PDLZellen (Lallier und Spencer 2007).

Aus dieser Literatur und zahlreichen anderen Quellen geht hervor, dass sich Untersuchungen an PDL-Zellen bisher nur auf solche Zähne beschränkt haben, welche keinerlei Läsionen aufwiesen und deren Parodontium entzündungsfrei war. Im Rahmen dieser Arbeit wurden erstmals Untersuchungen auch an PDL-Gewebe vorgenommen, welches parodontitisch erkrankten Zähnen entstammte und folglich auch eine modifizierte Vorgehensweise in der Zellkultur erforderlich machte. Der Hintergrund für diesen Ansatz war die Vorstellung, dass in erkranktem Gewebe der regenerative Anspruch an Zellen des Parodontalligaments erhöht ist. Dieser wiederum könnte auf eine evtl. erhöhte Expression der entsprechenden Eigenschaften schließen lassen.

\subsection{Allgemeines zur Zellkultur und zu den eingesetzten Antibiotika}

Für die von der Zahnoberfläche gewonnene Gewebeprobe und die in ihr enthaltenen Zellen muss auch unter in-vitro-Bedingungen eine Umgebung vorhanden sein, die Proliferation, Wachstum und Differenzierung ermöglicht und welche die Aufrechterhaltung der typischen Zellfunktionen gewährleistet. Um diese Faktoren sicherzustellen, werden den Zellen alle nicht von innen selbst produzierbaren Substanzen wie z.B. verschiedene Aminosäuren und Vitamine mittels Medium zugeführt. Die von den Zellen metabolisierten Produkte werden durch ein im Medium enthaltenes anorganisches Puffergemisch neutralisiert. Das Minimalmedium nach Dulbecco enthält gegenüber dem Minimalmedium nach Eagle teilweise die doppelte Menge an Aminosäuren und die vierfache Menge mancher Vitamine, wodurch das Medium weniger häufig gewechselt werden muss. Diesen Kulturmedien muss ein Serum zugefügt werden, welches Hormone, zahlreiche für die Synthese von Proteinen benötigte Aminosäuren, anorganische Salze und weitere Substanzen wie z.B. Spurenelemente enthält. Auf diesem Weg ist ein optimales Wachstum der Zellen in der Kultur sichergestellt. Die Seren können von neugeborenen oder älteren Kälbern, Pferden, Schweinen oder sogar vom Menschen stammen. Für die Versuche dieser Arbeit wurde fetales Kälberserum verwendet. 
Auch für Bakterien und Viren stellen die Zellkulturmedien außergewöhnlich gute Nährböden dar, in denen sie sich innerhalb kürzester Zeit stark vermehren können. Wichtige Nährstoffe werden von den Bakterien verbraucht und die gebildeten Metabolite und Zerfallsprodukte können die Kultur irreversibel schädigen, was die Zugabe von Antibiotika erforderlich macht. Die eingesetzte Standard-Antibiose beinhaltet Dihydrostreptomycinsulfat (Streptomycin A) und Penicillin-G Natrium (Lindl und Bauer 2002). Gegen Pilzbefall wird Amphotericin B eingesetzt. Zusätzlich zu den genannten Antibiotika finden Metronidazol, Amoxicillin, Ciprofloxacin und Gentamycin Verwendung.

Streptomycin und Gentamycin sind Aminoglykosid-Antibiotika. Hinsichtlich ihres Wirkungsmechanismus zeichnen sie sich durch ein breites Wirkungsspektrum, eine bakterizide Wirkung und einen schnellen Wirkungseintritt aus. Eingesetzt werden sie vornehmlich bei Infektionen mit gramnegativen Stäbchen (Aggregatibacter actinomycetemcomitans, Porphyromonas gingivalis, Tannerella forsythensis, Prevotella intermedia). Ein Vorteil der Aminoglykosid-Antibiotika ist, dass sie nicht nur durch die Poren, sondern auch direkt durch die Lipopolysaccharid-Doppelschicht der äußeren Bakterienmembran ins Innere vordringen können. Liegen sie im Zytoplasma der Bakterien vor, binden sie an die 30S-Untereinheit der Ribosomen. Die Proteinsynthese ist fehlgesteuert und es resultieren funktionsuntüchtige Proteine. Aminoglykoside zeigen eine konzentrationsabhängige Bakterizidie. Je höher die Konzentration ist, desto mehr nehmen Ausmaß und Geschwindigkeit der Bakterizidie zu. Dabei lässt sich ein postantibiotischer Effekt feststellen. In vitro ist eine Bakterienzelle nach Kontakt zu einem Aminoglykosid für ca. 3-6 Stunden gehemmt, auch wenn der Wirkstoff aus der Umgebung entfernt wurde. Überlebt die Bakterienzelle die erste Exposition, ist sie in ihrer Funktion stark beeinträchtigt. Eine rasch folgende zweite Exposition erzielt eine deutlich geringere Wirksamkeit („transitorische Resistenz"). Eine einmalig hohe Dosis kann daher wirksamer sein als mehrmalige kleinere Dosen. Das Wirkungsspektrum gegen Bakterien ist im basischen Milieu sehr breit. Alle Anaerobier sind gegen Aminoglykoside resistent. Sensibel sind jedoch Staphylococcus aureus, Koagulase-negative Staphylokokken sowie A-Streptokokken.

Penicillin $G$ und Amoxicillin sind $\beta$-Lactam-Antibiotika. Der $\beta$-Lactam-Ring ist das Charakteristikum dieser Gruppe. Dieser blockiert durch Acylierung das aktive 
Zentrum von zellwandaufbauenden Enzymen wie z.B. die bakterielle Peptidoglykansynthetase (Mureinsynthetase). Die Folge sind so große Defekte in der Zellmembran, dass der intrabakterielle osmotische Druck die Zytoplasmamembran zerreißt. Penicillin G und Amoxicillin sind wirksam gegen (fakultativ) aerobe grampositive Bakterienarten wie z.B. Strepto- und Pneumokokken, Actinomyces und Treponemen und gegen anaerobe gramnegative Stäbchen (Actinobacillus actinomycetemcomitans, Fusobakterien) und Spirochäten.

Metronidazol gehört zu der Gruppe der Nitroimidazole. Nitroimidazole selbst sind antimikrobiell unwirksam, sie werden erst intramikrobiell zu Metaboliten umgewandelt, die die DNA angreifen können. Metronidazol ist überwiegend wirksam gegen anaerobe Keime, beispielsweise gegen Fusobakterien, Peptostreptokokken und Prevotella-Spezies (Porphyromonas gingivalis, Bacteroides forsythus, Prevotella intermedia).

Ciprofloxacin wird der Gruppe der Chinolon-Antibiotika („Gyrasehemmer“) zugeordnet. Angriffsorte dieser Substanzen sind die bakteriellen Topoisomerasen, deren Aktivität die richtige Struktur und Funktion der bakteriellen DNA sicherstellt. Ciprofloxacin zeichnet sich durch eine starke Wirksamkeit gegen Enterobakterien, grampositive Kokken (Staphylococcus aureus und epidermis, Streptococcus pyogenes u.a.) und andere gramnegative Bakterien (Neisserien, Pseudomonas aeruginosa und Haemophilus influenzae) aus (Aktories et al. 2005). Mykoplasmen, durch welche eine Zellkultur oft kontaminiert wird, werden mit Ciprofloxacin ebenfalls effektiv eliminiert (Lindl und Bauer 2002).

Amphotericin B ist ein Polyen-Antimykotikum und wird aus Streptomyces-Arten isoliert. Antimykotika greifen in ihrer Wirkung hauptsächlich die Zellwand (aufgebaut aus Polysacchariden und Chitin) und die Zellmembran (Ergosterin) der Pilze an. Amphotericin B besitzt eine hydrophobe und eine hydrophile Seite. Sowohl Amphotericin B als auch das Ergosterin der Zellmembran weisen ein hydrophobes, starres und durchkonjugiertes Doppelbindungssystem auf, das exakt zueinander passt. Bei einer Anlagerung von Amphotericin B an Ergosterin wird diese durch die Hydrophobie der Molekülflächen maximal gefestigt. Die hydrophile Seite des Amphotericin B ist nun jedoch den Phospholipiden der Membran zugekehrt, wodurch sich deren Verband durch Poren- und Kanalbildung auflockert. Amphotericin-Bsensibel sind u.a. Candida-Arten und Aspergillus fumigatus. Bakterien sind hingegen 
unempfindlich gegen Amphotericin B, da sie keine Membransterine besitzen (Aktories et al. 2005).

\subsection{Zielsetzung und Aufgabenstellung}

Mit vorliegender Arbeit soll das Wissen zum Vorkommen und der Expression verschiedener Oberflächenantigene auf PDL-Zellen sowohl gesunder als auch parodontitisch erkrankter Zähne erweitert werden. Dass explantierte humane PDLZellen aus gesundem bzw. erkranktem Zahnhalteapparat unterschiedliche Expressionsmuster zeigen, wurde bereits von unserer Arbeitsgruppe mittels in-vivoMicroarray nachgewiesen (Brietze 2007). In dieser Dissertation sollen mit Hilfe einer ex-vivo-Zellkultur, der real-time (RT)-PCR und dem FACS (Fluorescence Activated Cell Sorting) verschiedene Adhäsionsmoleküle (CD29, CD44), die Immunantwort modulierende Faktoren (CD13, Runx2, CD73) und Bestandteile der extrazellulären Matrix (Col I, CD44) weiter untersucht werden.

Das Ziel dieser Arbeit ist es, eine ex-vivo-Zellkultur parodontitisch erkrankter Parodontalligamentzellen $\mathrm{zu}$ entwickeln und anhand dieser eine vergleichende Charakterisierung zwischen Zellen aus erkrankten Parodontien und gesunden Parodontalligamentzellen durchzuführen.

Die zentrale Aufgabenstellung der vorliegenden Arbeit lautet daher:

1. Etablierung einer Zellkultur aus humanen parodontitisch erkrankten und gesunden Zellen des Parodontalligaments

2. Nachweis der Unterschiede im Genexpressionsmuster aus der Gruppe der Adhäsionsmoleküle, der die Immunantwort modulierenden Faktoren und der Bestandteile der extrazellulären Matrix des gesunden Parodontiums im Vergleich zur chronischen Parodontitis 


\section{Material und Methoden}

\subsection{Probenmaterial}

\subsubsection{Patientenkollektiv und Gewebepräparation}

Die Gewebeproben stammen von sechs Patienten (drei Frauen und drei Männer) im Alter von 17-55 Jahren (Durchschnittsalter 36 Jahre), die sich im Zeitraum von August 2007 bis Juni 2008 in zahnärztlicher Behandlung im Universitätsklinikum Göttingen befanden. Die Entnahme des entzündeten Probenmaterials erfolgte von extrahierten Zähnen, die aufgrund fortgeschrittener chronischer Parodontitis nicht länger erhaltungswürdig waren. Zähne, welche im Rahmen einer kieferorthopädischen Behandlung entfernt wurden, dienten der Gewinnung gesunden Gewebes aus dem Zahnhalteapparat. Anhand klinischer, für die chronische Parodontitis typischer Parameter, wie z.B. erhöhte Sondierungstiefen, Blutung auf Sondierung (BOP), Attachmentverlust, erhöhte Zahnbeweglichkeit und radiologischer Knochenverlust, ließen sich die gesunden von parodontitisch erkrankten Gewebeproben unterscheiden. Bei jedem Patienten wurde darüber hinaus eine umfassende Anamnese erhoben, so dass zu jeder Gewebeprobe auch Informationen über Allgemeinerkrankungen des zugehörigen Patienten (z.B. Diabetes mellitus, Herzerkrankungen etc.) sowie über Medikamenteneinnahme und Nikotinkonsum vorlagen. Zur eigentlichen Untersuchung wurden die Proben von sechs Patienten ohne gravierende Allgemeinerkrankung ausgewählt.

Die Gewinnung des Gewebes wurde auf das mittlere Wurzeldrittel und gingivale Gewebe beschränkt, um die mikrobiologischen Einflüsse aus der Mundhöhle (wie z.B. eine aktive Karies) einerseits und aus dem Knochen (z.B. durch eine Parodontitis apicalis) andererseits möglichst gering zu halten.

Die teilnehmenden Patienten wurden über die Hintergründe dieser Studie aufgeklärt. Die Studie wurde durch die Ethikkommission der Medizinischen Fakultät der Universität genehmigt (Ethikantrag Nr. 27/2/09).

\subsubsection{Zellkultur}

\subsubsection{Kultivierung der PDL-Zellen}

Die Kultivierung der PDL-Zellen erfolgte unter sterilen Bedingungen, d.h. die Gewebepräparation und das Passagieren der angezüchteten Zellen wurden unter 
einer Sterilbank mit autoklavierten Pipetten und Gefäßen sowie auf einer mit Alkohol desinfizierten Arbeitsfläche vorgenommen.

Die Zeit zwischen Extraktion und Verarbeitung der Zähne betrug nicht mehr als 24 Stunden. Das Gewebe wurde über einer Petrischale mit Pinzette und Einwegskalpell (Cutfix Surgical Disposable, B. Braun Surgical GmbH, Melsungen) abgeschabt und in ein Plastikröhrchen mit $5 \mathrm{ml}$ PBS (phosphate buffered saline, phosphatgepufferte Salzlösung) ohne Penicillin/Streptomycin (P/S) gegeben. Darauf folgte eine zwei- bis dreimalige Spülung mit PBS bei 1000 U/min für je zwei Minuten. Der Verdau erfolgte mittels Collagenase I und II (5 mg auf $10 \mathrm{ml}$ Medium) und Dispase (1,04 Units/mg) für eine Stunde. Danach wurde mit $10 \mathrm{ml}$ PBS ohne P/S erneut gewaschen und eine Kultur mit Dulbecco's Modified Eagle Medium (DMEM-Medium, Biochrom, Berlin) und spezifischer Antibiose angesetzt.

Je nach Kontaminationslevel erfolgte für einige Nächte eine Prä-Kultur mit spezifischer Antibiose (siehe unten). Nach zwei Tagen wurde erneut eine Antibiose dazugegeben und alle 2 Tage ein Mediumwechsel durchgeführt. Das Anzüchten der Zellen wurde in Abhängigkeit von der Menge des abgeschabten Materials in 6-Wellund 24-Well-Platten mit $3 \mathrm{ml}$ bzw. $500 \mu \mathrm{l}$ Medium oder in Zellkulturfläschchen $(5 \mathrm{ml})$ vorgenommen. Bei ausreichender Konfluenz erfolgte die Passage.

\subsubsection{Herstellung des Kulturmediums}

Die Parodontalligament (PDL)-Zellen wurden in DMEM-Medium der Firma Biochrom kultiviert. Diesem Medium wurden 10 Vol.-\% fetales Kälberserum hinzugefügt. Vor Gebrauch wurde das Medium auf $37^{\circ} \mathrm{C}$ erwärmt und sonst bei $4^{\circ} \mathrm{C}$ aufbewahrt.

\subsubsection{Entwicklung der spezifischen Antibiose}

Mit den in variablen Konzentrationen in umfangreichen Vorversuchen eingesetzten Antibiotika Ciprofloxacin, Gentamycin und Streptomycin konnte der für parodontale Läsionen spezifischen bakteriellen Kontamination dieser Versuchsreihen nicht wirksam begegnet werden. Die Ausführungen über die eingesetzten Konzentrationen beschränken sich hier daher nur auf die Antibiotika, die anschließend den Zellkulturen zugesetzt worden sind, die für die Ergebnisse dieser Arbeit von Bedeutung waren. 
Die dem herkömmlichen Standard-Medium hinzugefügten Antibiotika Streptomycin A und Penicillin-G Natrium haben jeweils die Konzentrationen von 100 mg/ml bzw. 100 $\mathrm{IU} / \mathrm{ml}$. Das Medium mit diesem antibiotischen Zusatz wurde nur für die Primärkultur mit PDL-Gewebe aus gesundem Zahnhalteapparat verwendet. Zusätzlich enthielt dieser Ansatz Amphotericin B. Bei der Primärkultur mit PDL-Gewebe aus parodontitisch geschädigtem Zahnhalteapparat enthielt das Medium kein Streptomycin A und Penicillin-G Natrium, sondern die keimspezifische Antibiose aus Amphotericin B, Amoxicillin und Metronidazol. Nach zwei Tagen erfolgte für beide Ansätze die Zugabe von Antibiotika entsprechend der Primärkultur. Nach 4-6 Tagen wurden das Medium gewechselt und der Kontaminationsstatus unter dem Mikroskop (Zeiss Axiovert $40 \mathrm{CFL}$, Carl Zeiss Jena $\mathrm{GmbH}$, Jena) kontrolliert. Nach Bedarf wurde dem Zellkulturansatz dann das erforderliche Antibiotikum hinzugefügt.

Bis auf die Konzentrationen von Streptomycin A und Penicillin-G Natrium waren die einzusetzenden Konzentrationen der anderen Antibiotika unklar, es war lediglich die zytotoxische Konzentration von Amphotericin B $(30 \mu \mathrm{g} / \mathrm{ml})$ bekannt. Metronidazol und Amoxicillin werden klinisch bei der chronischen Parodontitis im Verhältnis 1:1,5 eingesetzt. Dieses Verhältnis ist für die Versuche übernommen worden. Im Rahmen der Zellkultur der vorliegenden Arbeit war es daher hinsichtlich der Konzentrationen der Antibiotika von zentraler Bedeutung, ein Gleichgewicht zwischen wirksamer Bekämpfung der bakteriellen Kontamination einerseits und ihrer Zytotoxizität andererseits zu entwickeln. Ausgehend von den bekannten Konzentrationen anderer in der Zellkultur angewendeter Antibiotika mit zytotoxischer Wirkung (Chloramphenicol: zytotoxisch ab $30 \mu \mathrm{g} / \mathrm{ml}$, empfohlen sind $5 \mu \mathrm{g} / \mathrm{ml}$; Gentamycin: zytotoxisch ab $3000 \mu \mathrm{g} / \mathrm{ml}$, empfohlen sind $50 \mu \mathrm{g} / \mathrm{ml}$; Tetracyclin Base: zytotoxisch ab $35 \mu \mathrm{g} / \mathrm{ml}$, empfohlen sind $10 \mu \mathrm{g} / \mathrm{ml}$ ) wurden die Versuche zunächst mit höheren Konzentrationen begonnen. Ergab die Kontaminationskontrolle durch eine bestimmte Antbiotikumkonzentration eine Keimverringerung, so wurde bei dem darauffolgenden Versuchsansatz eine niedrigere Konzentration eingesetzt um auszutesten, ob mit dieser ebenfalls eine Keimreduktion möglich ist, allerdings mit geringerem zytotoxischen Effekt. Es folgten verschiedene Kombinationen der Antibiotikakonzentrationen. Die verwendeten Konzentrationen sahen dabei wie folgt aus: 


\begin{tabular}{|c|c|c|c|c|c|c|}
\hline $\begin{array}{c}\text { Konzentration } \\
1\end{array}$ & Konzentration & Konzentration & Konzentration & Konzentration & Konzentration & Konzentration \\
\hline $12 \mu \mathrm{g} / \mathrm{ml}$ & $10 \mu \mathrm{g} / \mathrm{ml}$ & $5 \mu \mathrm{g} / \mathrm{ml}$ & $4 \mu \mathrm{g} / \mathrm{ml}$ & $3,5 \mu \mathrm{g} / \mathrm{ml}$ & $3 \mu \mathrm{g} / \mathrm{ml}$ & $2 \mu \mathrm{g} / \mathrm{ml}$ \\
\hline
\end{tabular}

Tab. 1: Entwicklung der Konzentrationen von Amphotericin B

\begin{tabular}{|c|c|c|}
\hline $\begin{array}{c}\text { Konzentration } \\
1\end{array}$ & $\begin{array}{c}\text { Konzentration } \\
2\end{array}$ & $\begin{array}{c}\text { Konzentration } \\
3\end{array}$ \\
\hline $52,5 \mu \mathrm{g} / \mathrm{ml}$ & $37,5 \mu \mathrm{g} / \mathrm{ml}$ & $35 \mu \mathrm{g} / \mathrm{ml}$ \\
\hline
\end{tabular}

Tab. 2: Entwicklung der Konzentrationen von Amoxicillin

\begin{tabular}{|c|c|}
\hline $\begin{array}{c}\text { Konzentration } \\
1\end{array}$ & $\begin{array}{c}\text { Konzentration } \\
2\end{array}$ \\
\hline $35 \mu \mathrm{g} / \mathrm{ml}$ & $25 \mu \mathrm{g} / \mathrm{ml}$ \\
\hline
\end{tabular}

Tab. 3: Entwicklung der Konzentrationen von Metronidazol

Die Antibiose für einen Zellkulturansatz mit PDL-Zellen aus gesundem Zahnhalteapparat setzte sich zusammen aus $100 \mu \mathrm{g} / \mathrm{ml}$ bzw. $100 \mathrm{IU} / \mathrm{ml}$ Streptomycin A und Penicillin-G Natrium sowie $5 \mu \mathrm{g} / \mathrm{ml}$ Amphotericin B.

Die spezifische Antibiose für einen Zellkulturansatz aus PDL von parodontitisch erkrankten Zähnen bestand final aus $5 \mu \mathrm{g} / \mathrm{ml}$ Amphotericin B, 37,5 $\mu \mathrm{g} / \mathrm{ml}$ Amoxicillin und $25 \mu \mathrm{g} / \mathrm{ml}$ Metronidazol.

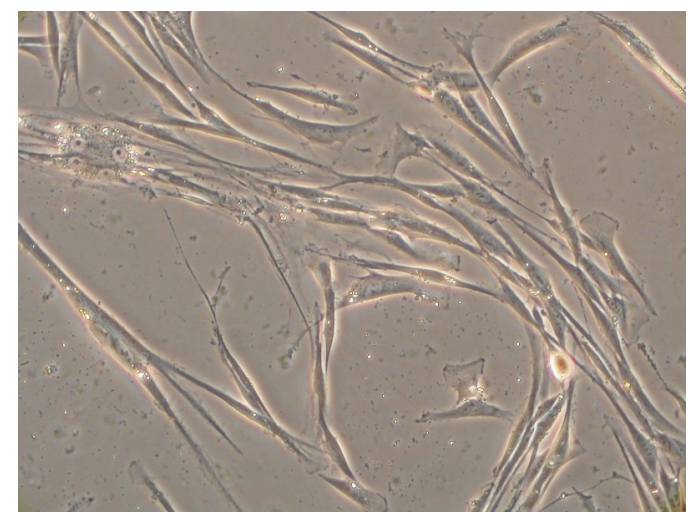

Abb. 2: Bakteriell leicht kontaminierte Zellkultur

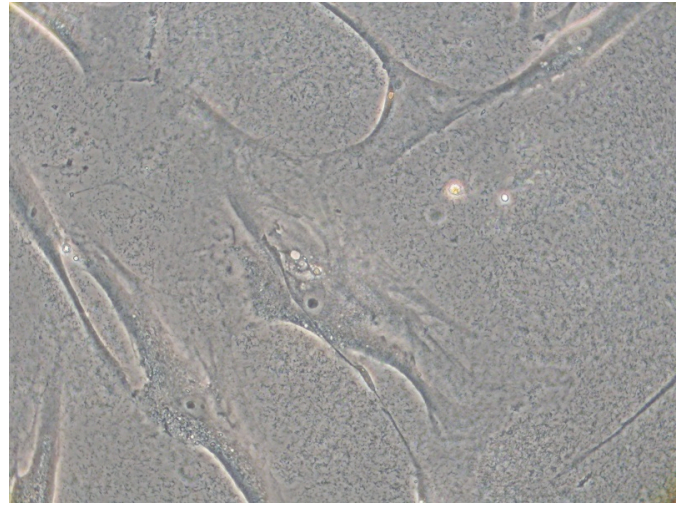

Abb. 3: Bakteriell stark kontaminierte Zellkultur 


\subsubsection{Ernte der PDL-Zellen}

War eine ausreichende Konfluenz der Zellen erreicht, wurde das Kulturmedium von den Zellen mit Hilfe einer Pasteurpipette und einer Pumpe abgesaugt. Die Zellen wurden mit $5 \mathrm{ml}$ PBS für eine Minute gewaschen, um Reste des FCS, welche das 0,1\%ige Trypsin/EDTA (TE, 0,5 mM) inaktivieren würden, zu entfernen. Anschließend wurde das PBS erneut abgesaugt und TE (2 ml für eine große Zellkulturflasche) auf die Zellen gegeben, welche dann für maximal zehn Minuten in einen Inkubator mit einer Temperatur von $37^{\circ} \mathrm{C}$ gestellt wurden. Hatten sich die Zellen vollständig abgelöst, erfolgte eine Inaktivierung des TE durch Serum (FCS). Die Suspension wurde für acht Minuten bei $1200 \mathrm{U} / \mathrm{min}$ zentrifugiert und der Überstand verworfen. Daraufhin erfolgte entweder die erneute Aussaat im Verhältnis 1:3 oder eine direkte Verwendung der Zellen zur Protein-Analyse mittels Fluorescence Activated Cell Sorting (FACS) bzw. die RNA-Isolierung. Hierfür wurde auf das Pellet $350 \mu \mathrm{l}$ RLT-Puffer (RLT+ $\beta$-Mercaptoethanol) gegeben.

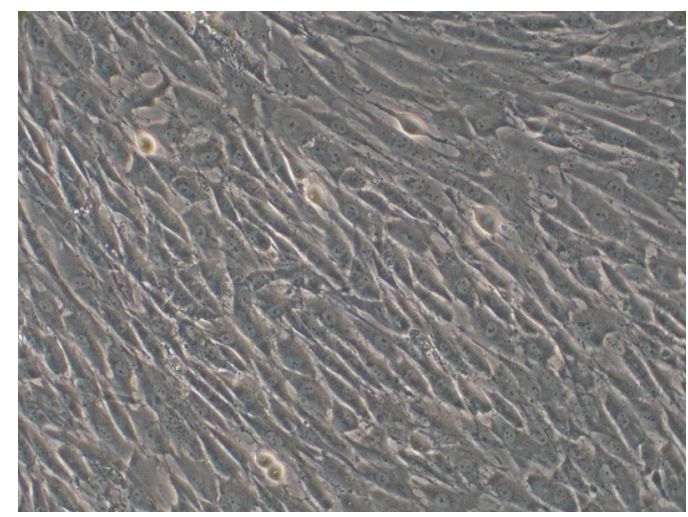

Abb. 4: Sehr konfluente Zellkultur

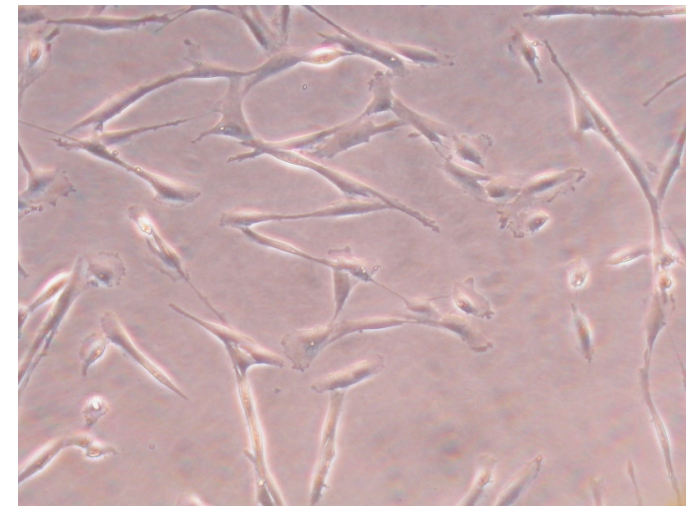

Abb. 5: Morphologie der Zellen aus gesundem Parodont

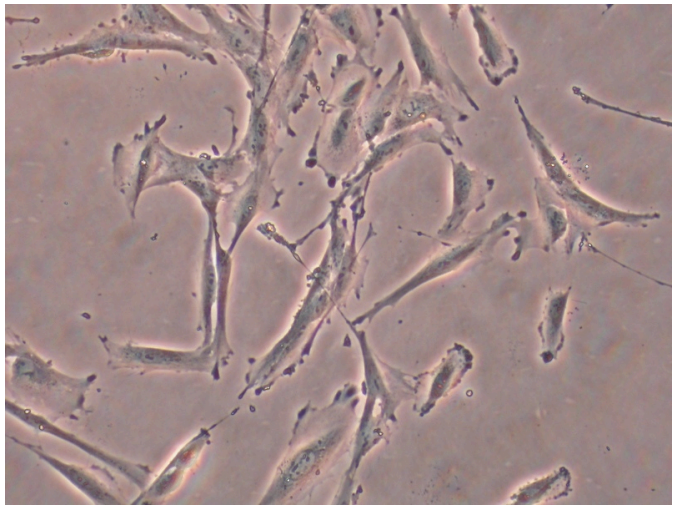

Abb. 6: Morphologie der Zellen aus parodontitisch erkranktem Parodont 


\subsubsection{5 mRNA-Isolierung aus dem PDL}

Die Isolierung der Gesamt-RNA wurde mit dem RNeasy mini Kit (Qiagen, Hilden) durchgeführt. Um eine Kontamination durch RNAse z.B. von der Haut und der Umgebung zu vermeiden, wurde mit Handschuhen und RNAse-freien Geräten und Gefäßen gearbeitet. Bei dem Vorgang der Extraktion der Gesamt-RNA werden die zelluläre RNA von umgebenden Zellkomponenten getrennt und die ubiquitär vorhandenen RNasen gleichzeitig inaktiviert. Dem Funktionsprinzip des RNeasy mini Kit liegt eine spezifische Aufreinigung der RNA über hydrophile Siliziumgel-Säulen unter Verwendung geeigneter Puffersysteme zu Grunde. Das Kit ist hierfür mit RNeasy Mini Säulen, RPE-, RW1-, RLT-Puffer, QIA Shredder und RNase free water ausgestattet. Bei der Gewinnung wird ein Gesamt-RNA-Volumen von etwa $25 \mu \mathrm{l}$ angestrebt. Der Ablauf der Isolierung folgte dem Protokoll des Herstellers und wurde nur an einer Stelle geringfügig modifiziert:

Zum Schluss wurden statt der im Herstellerprotokoll vorgeschriebenen 30-50 $\mu \mathrm{l} 100$ $\mu$ l RNAse-freies Wasser direkt auf die Membran der Säule pipettiert, welche sich in einem 1,5 ml Eppendorf Biopur ${ }^{\circledR}$ tube (Fa. Eppendorf, Hamburg) befand. Nach einer Inkubationszeit von 5 Minuten bei Raumtemperatur wurde das Eppendorf Biopur ${ }^{\circledR}$ tube mit der RNeasy Mini Säule für eine Minute bei 14.000 rpm zentrifugiert. Der Durchfluss enthielt nun die RNA. Die RNeasy Mini Säule wurde entfernt und das offene Biopur $^{\circledR}$ tube in einem Concentrator 5301 (Fa. Eppendorf, Hamburg) bei $30^{\circ} \mathrm{C}$ nach Sicht auf ca. $25 \mu$ l eingedampft.

\subsubsection{Konzentrationsbestimmung der Gesamt-RNA und Synthese der cDNA}

Ein $\mu \mathrm{l}$ der RNA-Probe wurde abgenommen und mit $9 \mu$ nuklease-freiem Wasser vermischt. Mittels photometrischer Messung (Photometer Gene Quant, Pharmacia, Freiburg) der Absorption einer Wellenlänge von $260 \mathrm{~nm}$ wurde die quantitative Konzentration der Probe bestimmt. Alle Proben sowie der Referenz-Leerwert aus nuklease-freiem Wasser wurden in einer Ultrospec Küvette (Typ 40008455) bestimmt. Das Absorptionsspektrum bei einer Wellenlänge von $260 \mathrm{~nm}$ entspricht dem Absorptionsmaximum der Pyrin- und Pyrimidin-Basen der RNA. Als ausreichend rein und damit auch für weitere Versuche verwendbar, werden RNALösungen angesehen, deren Ratio zwischen 1,8 und 2,0 liegt.

Mit Hilfe des QuantiTect Reverse Transcription Kit (Qiagen, Hilden) wird die RNA in eine doppelsträngige cDNA umgeschrieben. Da die Umsetzung von mRNA zu cDNA 
im Verhältnis 1:1 geschieht, erhält man aus z.B. 539,4 ng mRNA theoretisch die gleiche Menge an cDNA. Die Durchführung folgte den Angaben des HerstellerProtokolls. Bis zu ihrer Verwendung wurde die umgeschriebene cDNA bei $-20^{\circ} \mathrm{C}$ gelagert.

\subsection{Real-time (RT)-PCR}

Um die mittels FACS erhaltenen Ergebnisse der Protein-Charakterisierung vergleichend für die mRNA-Expression evaluieren zu können, wurde die Nachweismethode der real-time (RT)-PCR herangezogen. Untersucht wurden dabei jeweils die Expression von sechs Genen (Kollagen Typ I, Runx2, CD13, CD73, CD44, CD29) der Zellen aus dem PDL der Zähne von drei parodontitisch erkrankten und zwei gesunden Patienten. Als Housekeeping-Gen wurde Beta2Mikroglobulin $(\beta 2 \mathrm{M})$ benutzt. $\beta 2 \mathrm{M}$ zeigte in den verschiedenen Gewebeproben stabile und gleiche Expressionsaktivitäten und war daher als Referenzgen geeignet.

\begin{tabular}{lllcc}
\hline Transcript & Forward Primer & $\begin{array}{l}\text { Reverse } \\
\text { Primer }\end{array}$ & $\begin{array}{l}\text { Länge } \\
(\mathrm{Bp}=\text { Basenpaare })\end{array}$ & $\begin{array}{c}\text { Annealing } \\
\text { temp. in }{ }^{\circ} \mathrm{C}\end{array}$ \\
\hline Col I & ttcccccagccacaaagagtc & cgtcatcgcacaacacct & 261 & 61.0 \\
RUNX2 & ttccagaccagcagcactc & cagcgtcaacaccatcatt & 181 & 63.0 \\
CD13 & tggttcaatgaggctgacaag & ggacaaagtcccagaccaga & 180 & 61.5 \\
CD73 & aaggaaggggaagaacag & gaagaaagaggacagagg & 168 & 56.0 \\
CD44 & gtggaagattggacagga & gtgtgtgggtaatgagagg & 229 & 59.0 \\
CD29 & ctgattggctggaggaatg & tttctggacaaggtgagca & 186 & 56.0 \\
B2M & tgctgtctccatgttgatgtatct & tctctgctccccacctctaa & 86 & 61.0 \\
\hline
\end{tabular}

Tab. 4: Oligonukleotidprimer für die real-time (RT)-PCR

\subsubsection{Primerdesign}

Die für diese Nachweise erforderlichen spezifischen Primersequenzen wurden der Datenbank des NCBI (NCBI Blast: Nucleotide-nucleotide Blast (blastn), http://www.ncbi.nlm.nih.gov (2007)) entnommen. Prämissen für das Primer-Design waren, dass die Primer eine maximale Länge von 18-22 Basen haben und der Gehalt der Basen Guanin und Cytosin ungefähr 50\% beträgt. Die spezifische Schmelztemperatur für die Primer sollte zwischen $50-65^{\circ} \mathrm{C}$ liegen. Um Alignments von Genen, deren Sequenz denen der Primersequenz ähnelt, ausschließen zu 
können, erfolgte ein Abgleich der ausgewählten Primer bei der Online-Datenbank von NCBI. Die Herstellung der Primer erfolgte durch die Firma Operon Biotechnologie $\mathrm{GmbH}$ (Operon Biotechnologie $\mathrm{GmbH}$, Köln). Nach Angaben des Herstellers wurden die gefriergetrockneten Primer mit RNase-freiem Wasser resuspendiert und in einer Konzentration von $10 \mathrm{pmol}$ bei $-20^{\circ} \mathrm{C}$ gelagert.

\subsubsection{Verifizierung der Gen-Sequenzen}

Die von den Sequence Laboratories Göttingen $\mathrm{GmbH}$ übermittelten Nukleotidsequenzen wurden mit denen in der NCBI-Nukleotiddatenbank (http://www.ncbi.nlm.nih.gov (2007)) abgeglichen, wodurch ermittelt werden konnte, ob das entstandene PCR-Produkt dem für den Primer spezifischen Ziel-Gen entspricht. War dies der Fall, konnten diese Primer für die Untersuchungen mit der real-time (RT)-PCR verwendet werden.

\subsubsection{Durchführung der real-time (RT)-PCR}

Die Quantifizierung der spezifischen cDNA-Mengen der jeweiligen Probe erfolgte mittels der real-time (RT)-PCR. Der Pipettieransatz setzte sich wie folgt zusammen:

\begin{tabular}{|ll|}
\hline Substanz & Menge in $\mu l$ \\
SYBR-Green (RealMaster & 4,5 \\
Mix) & \\
RNAse-freies Wasser & 2,5 \\
Primer (for und rev) & 2 \\
cDNA einer Probe & 1 \\
\hline
\end{tabular}

Tab. 5: Pipettieransatz pro Gen und Well

Mit diesem aus $10 \mu$ bestehenden Ansatz wurde in dem Mastercycler ep realplex (Fa. Eppendorf, Hamburg) RT-PCR durchgeführt. Der Ablauf einer jeden PCR folgte einem bestimmten Schema. Anfangs wurde für $2 \min$ bei $95^{\circ} \mathrm{C}$ die DNA denaturiert. Anschließend wiederholte sich 45-mal der aus einer Denaturierungs-, Anlagerungsund Elongationsphase bestehende Zyklus. Die Annealingtemperatur der Anlagerungsphase variierte je nach eingesetztem Primer. An die ersten vier Phasen 
schloss sich die Generierung einer Schmelzkurve an, graphisch wiedergegeben durch die Messung der Extinktion des SYBR Greens I.

\begin{tabular}{|c|c|c|c|c|}
\cline { 2 - 4 } \multicolumn{1}{c|}{} & \multicolumn{3}{c|}{ Zyklenzahl: 45} & \multicolumn{1}{c|}{} \\
\hline $\begin{array}{c}\text { Initialdena- } \\
\text { turierung }\end{array}$ & $\begin{array}{c}\text { Denaturierungs- } \\
\text { phase }\end{array}$ & $\begin{array}{c}\text { Anlagerungs- } \\
\text { phase }\end{array}$ & $\begin{array}{c}\text { Elongations- } \\
\text { phase }\end{array}$ & Schmelzkurve \\
\hline $95^{\circ} \mathrm{C}, 2 \mathrm{~min}$ & $95^{\circ} \mathrm{C}, 3$ sek & $\begin{array}{c}\text { Variable } \\
\text { Annealingtemp., } \\
20 \text { sek }\end{array}$ & $68^{\circ} \mathrm{C}, 29$ sek & $\begin{array}{c}50-95^{\circ} \mathrm{C} \\
\text { Ramptime: } 20 \\
\text { sek }\end{array}$ \\
\hline
\end{tabular}

Tab. 6: PCR-Programm zur quantitativen Analyse der eingesetzten cDNA

Über die Messung der Extinktion der Fluoreszenz konnte die für jeden Primer spezifische Annealingtemperatur bestimmt werden. Das proportionale Verhältnis von gemessener Extinktion zu der im Ansatz vorhandenen cDNA ließ Rückschlüsse auf die Effektivität der Primer bei einer bestimmten Temperatur zu. So konnte die Temperatur mit der höchsten Extinktion als spezifische Annealing-Temperatur für den jeweiligen Primer festgelegt werden.

\subsection{FACS-Analyse}

\subsubsection{Antikörpermarkierung}

Die Zellen wurden für die extrazelluläre Markierung mit einem fluoreszenzfarbstoffkonjugierten Primärantikörper direkt markiert. Dazu wurden die Zellen in PBS resuspendiert und mit der jeweiligen Antikörperlösung in der Verdünnung 1:50 versetzt. Die Inkubation erfolgte über 30 Minuten bei $4^{\circ} \mathrm{C}$. Um nicht-gekoppelte Antikörper zu entfernen, wurden die Zellen gewaschen (Zentrifuge: $1200 \mathrm{U} / \mathrm{min}, 10$ min, Raumtemperatur) und anschließend erneut in PBS resuspendiert. Als Fluoreszenzfarbstoffe wurden Phycoerythrin (PE, rot) und Fluorescin-Isothiocyanat (FITC, grün) verwandt. 


\begin{tabular}{|l|l|}
\hline \multicolumn{1}{|c|}{ PE-Markierung } & \multicolumn{1}{c|}{ Hersteller } \\
\hline CD13 & BD Biosciences, San Jose, CA, USA \\
\hline CD29 & US Biological, Swampscott, MA, USA \\
\hline CD73 & BD Biosciences, San Jose, CA, USA \\
\hline & \\
\hline CD44 & Bender MedSystems GmbH, Wien, Austria \\
\hline
\end{tabular}

Tab. 7: Auflistung der Antikörper und deren extrazelluläre Markierung (direkt) einschließlich der Hersteller

Die intrazelluläre Markierung hingegen erfolgte über einen markierten Sekundärantikörper, der den unmarkierten Primärantikörper erkennt und bindet. Bei dieser Markierung wurde nach dem Protokoll des Fix \& Perm ${ }^{\circledR}$ Kits von Invitrogen verfahren (Invitrogen $\mathrm{GmbH}$, Karlsruhe). Als Fluoreszenzfarbstoff wurde FITC verwendet.

\begin{tabular}{|c|l|}
\hline Antikörper & \multicolumn{1}{c|}{ Hersteller } \\
\hline Col I & Millipore GmbH, Schwalbach/Ts. \\
\hline Runx2 & Santa Cruz Biotechnology, Inc., Heidelberg \\
\hline
\end{tabular}

Tab. 8: Auflistung der Antikörper einschließlich der Hersteller (intrazelluläre Markierung, FITC)

\subsubsection{Flow-zytometrische Analyse}

Die Analyse der Zellsuspension erfolgte, wie in der Einleitung beschrieben, mit Hilfe eines FACScan ${ }^{\text {TM }}$ der Firma Becton Dickinson, Heidelberg, (Argonlaser 488nm).

\subsubsection{Computergestützte Auswertung}

Die statistische Auswertung wurde mit dem WinMDI ${ }^{\circledR}$ Version 2.9 - Windows 3.95/DOS 5.0 Programm (Windows Multiple Document Interface; Flow-Cytometry Application) durchgeführt.

\subsubsection{Messung des Anteils der antigen-exprimierenden Zellen}

Die durchflusszytometrisch erfassten Zellen wurden abhängig von ihrer Größe (FSC) und ihrer Granularität (SSC) aufgetragen. Ein Analysefenster (Gate) wurde über die gemessene Zellpopulation gelegt. 


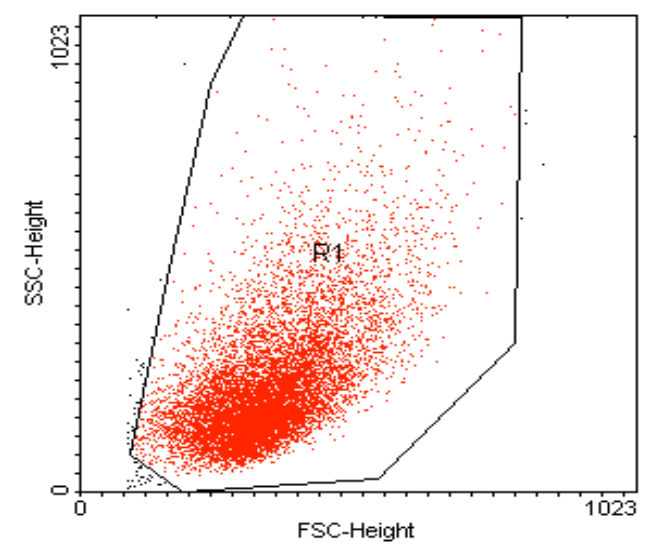

Abb. 7: Zellen im FSC/SSC-Dot-Plot. Zelltrümmer erscheinen als eine kleine diffuse Population am linken unteren Bildrand (schwarz dargestellt). Um die Fibroblastenpopulation ist zur weiteren Untersuchung ein Gate R1 gelegt worden

Innerhalb des Dot-Plot-Fensters können bestimmte Regionen definiert und zur Identifizierung der Eigenschaften der Zellpopulation verwendet werden. Dazu wird das Punktdiagramm in vier Quadranten aufgeteilt, in denen die Zellen in Abhängigkeit von ihren Zelleigenschaften bzw. ihrer relativen Fluoreszenz erscheinen.

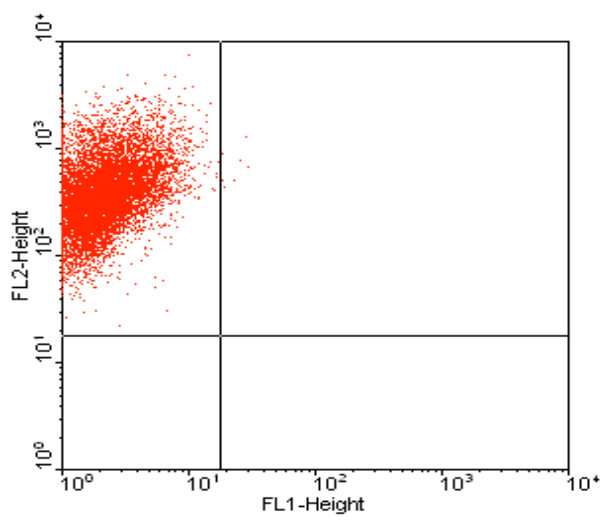

\begin{tabular}{|l|l|}
\hline Quadrant & Anteil der Zellen in \% \\
\hline Oben links & 97,92 \\
Oben rechts & 0,2 \\
Unten links & 0,07 \\
Unten rechts & 0,00 \\
\hline
\end{tabular}

Abb. 8 und Tab. 9: Darstellung der Zellen in einem FL 1/FL 2-Dot-Plot. Auswertung des Analysenergebnisses in graphischer und tabellarischer Form

Durch die Aufteilung der Punktdiagramme in vier Quadranten können die gemessenen Ereignisse antigenpositiven und antigennegativen Zellen zugeordnet werden. Von Bedeutung ist in diesem Beispiel besonders der linke obere Quadrant, in dem fast alle CD29-PE-markierten Zellen dargestellt sind. 


\subsection{Statistische Auswertung}

Die aus den real-time-(RT)-PCR- und FACS- Versuchen gewonnen Daten wurden in einer Excel $2008^{\circledR}$ - Tabelle zusammengetragen. Im Anschluss erfolgte die statistische Auswertung der Daten mit Statistika $2.0^{\circledR}$ in Zusammenarbeit mit den Mitarbeitern der Abteilung für Medizinische Statistik der Universitätsmedizin Göttingen unter der Leitung von Herrn Prof. Dr. T. Friede. Die graphische Darstellung der Verteilung der mit Hilfe von Statistika $2.0^{\circledR}$ ermittelten Daten erfolgt in Form von Box Plots der Rohdaten (Stichprobenumfang $n=3$ pro Gruppe), aufgeteilt nach den Gruppen "gesund“ mit parodontal gesundem PDL-Gewebe und „krank“ mit parodontal erkranktem PDL-Gewebe. In den Box Plots wird der Mittelwert als kleines Kästchen, der Mittelwert \pm Standardfehler SE als großer Kasten und der Mittelwert \pm $2 *$ Standardabweichung angezeigt.

Durch einen Signifikanztest wird es möglich, ein beobachtetes Ergebnis statistisch (mit einem geringen Irrtumsvorbehalt) vom Zufall abzugrenzen. Die statistische Auswertung erfolgt mit dem t-Test für zwei unabhängige Stichproben. Die aus den Untersuchungen gewonnenen Daten werden auf diese Weise auf statistisch signifikante Unterschiede hin verglichen. Die Signifikanz wird mit einem $p$-Wert $\leq$ 0,05 festgelegt, statistisch hochsignifikante Unterschiede liegen bei $p \leq 0,01$ vor. Bei $p>0,05$ ist der Unterschied statistisch nicht signifikant. Der p-Wert ist die Wahrscheinlichkeit, vorausgesetzt die Nullhypothese sei wahr (zumeist Formulierung der Gleichheit, also kein Expressionsunterschied zwischen gesundem und erkranktem Gewebe), dass die Teststatistik den beobachteten Wert annimmt. Ein kleiner $p$-Wert $(p$-Wert $\leq 0,05)$ bedeutet, dass es statistische Evidenz für einen Unterschied gibt. 


\section{Ergebnisse}

\subsection{Ergebnisse der real-time (RT)-PCR}

Zur Überprüfung der in der real-time (RT)-PCR gewonnenen Produkte wurde unmittelbar nach Ablauf einer PCR eine Schmelzkurvenanalyse durchgeführt. Diese würde Primer-Dimer-Formationen oder zusätzliche, nicht erwünschte Produkte erkennen lassen. Im Anschluss daran wurden die Ergebnisse durch die relative Quantifizierungsmethode nach Pfaffl (Pfaffl 2001) normalisiert.

\subsubsection{Schmelzkurvenanalyse}

Die Schmelzkurvenanalyse wurde unmittelbar nach jeder abgelaufenen real-time (RT)-PCR durchgeführt. Schmelzkurven werden aufgezeichnet, indem während eines langsamen Temperaturanstiegs die Fluoreszenzintensität der Reaktionsansätze kontinuierlich gemessen wird. Die Temperatur wird dabei in Schritten von $0,3^{\circ} \mathrm{C}$ zu je 8 Sekunden von $50^{\circ} \mathrm{C}$ bis auf $95^{\circ} \mathrm{C}$ erhöht. Wird die spezifische Schmelztemperatur des PCR-Produkts erreicht, denaturiert die bisher doppelsträngige DNA. Das bis zum jetzigen Zeitpunkt gebundene SYBR Green I liegt nun in ungebundenem Zustand vor, woraufhin kein Fluoreszenzsignal mehr messbar ist.

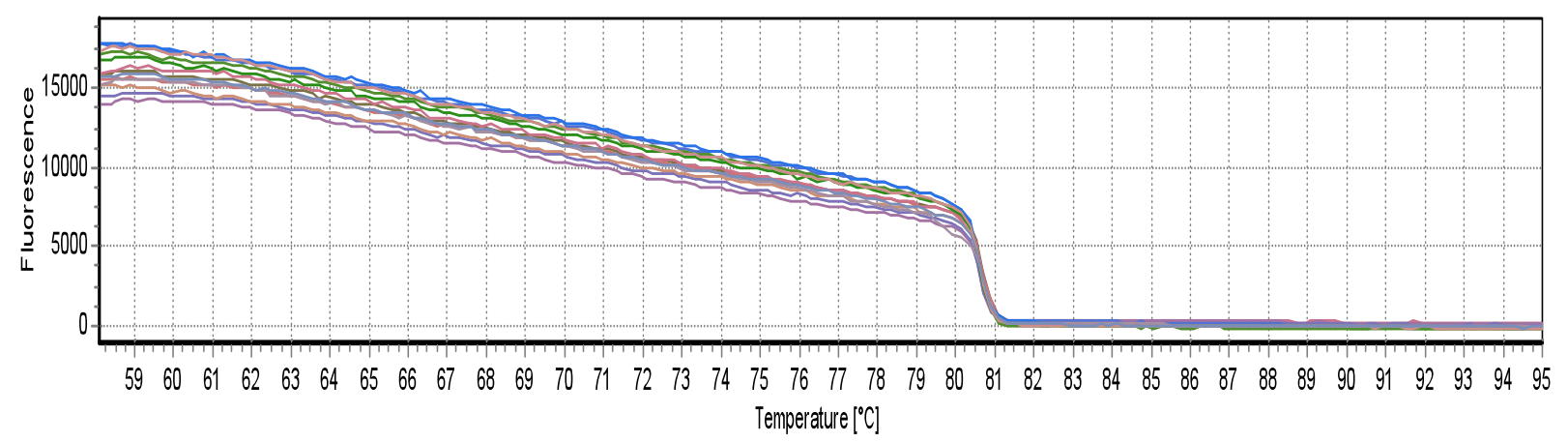

Abb. 9: Exemplarische Schmelzkurve eines spezifischen real-time (RT)-PCR-Produkts (hier CD 44), Ordinate: Fluoreszenzeinheiten (RFU)

Zur besseren Identifizierbarkeit der maximalen Intensitätsänderungen werden die Schmelzkurven als Peakkurven dargestellt. Bei den Peakkurven handelt es sich um 
die negative erste Ableitung der Schmelzkurven nach der Temperatur. Die Fluoreszenzintensität wird auf der Ordinate dargestellt. Die einfach zu erkennende Lage der Peakmaxima entspricht dann der Schmelztemperatur des Produkts.

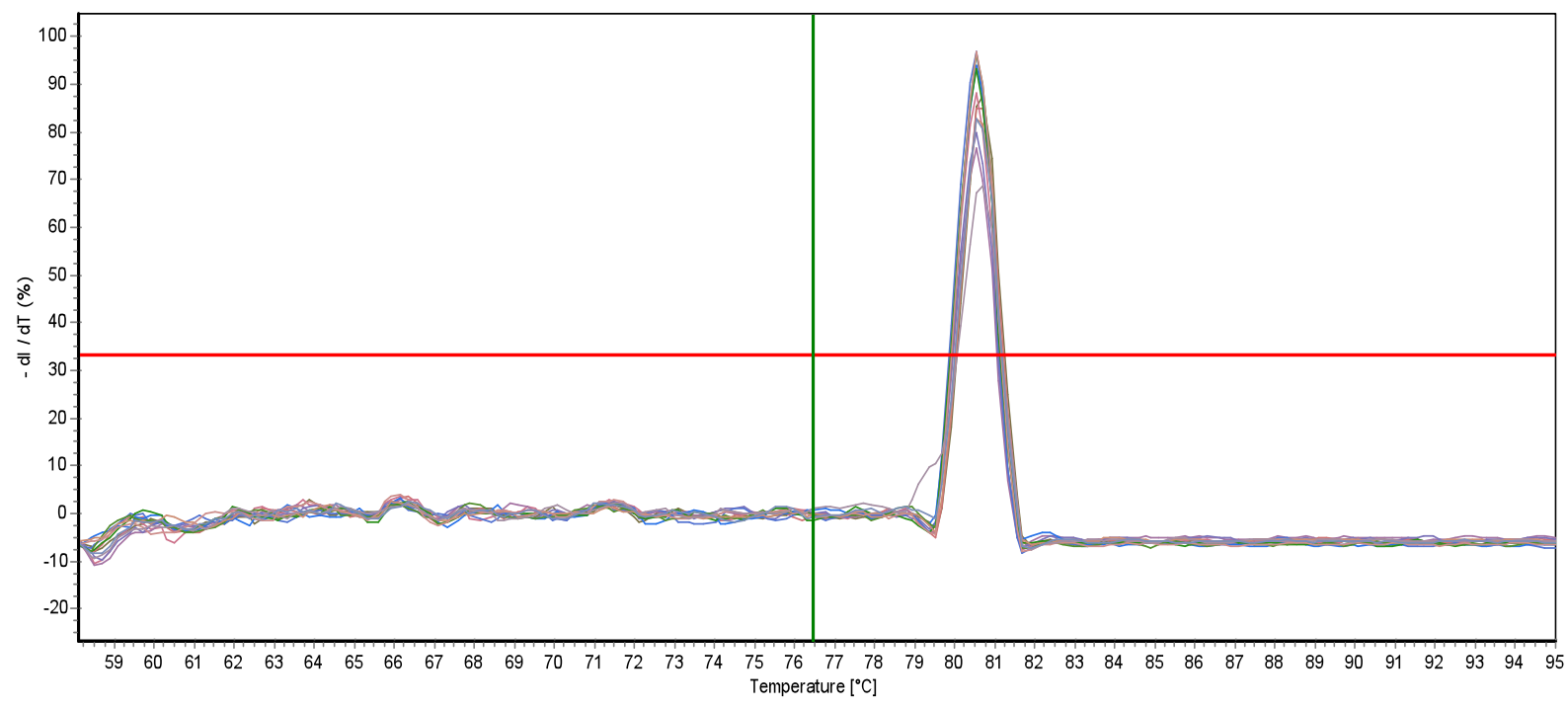

Threshold: $33 \%$

Abb. 10: Exemplarische Schmelzkurve eines spezifischen real-time (RT)-PCR-Produkts (hier CD44), Ordinate: Änderung der Fluoreszenzintensität : -dl/dT (\%)

Die Änderung der Relativen Fluoreszenzeinheiten (RFU) ist über die Temperatur aufgetragen. Die spezifischen PCR-Produkte der untersuchten RNA-Proben zeigen ein einheitliches Schmelzkurvenmaximum bei $80,5^{\circ} \mathrm{C}$.

Darüber hinaus lassen Schmelzkurvenanalysen zusätzlich entstandene, nicht erwünschte Produkte oder Primer-Dimere durch die Entstehung weiterer Maxima erkennen. Aufgrund ihrer geringeren Basenzahl zeigen Primer-Dimere eine deutlich niedrigere Schmelztemperatur als das PCR-Produkt. 


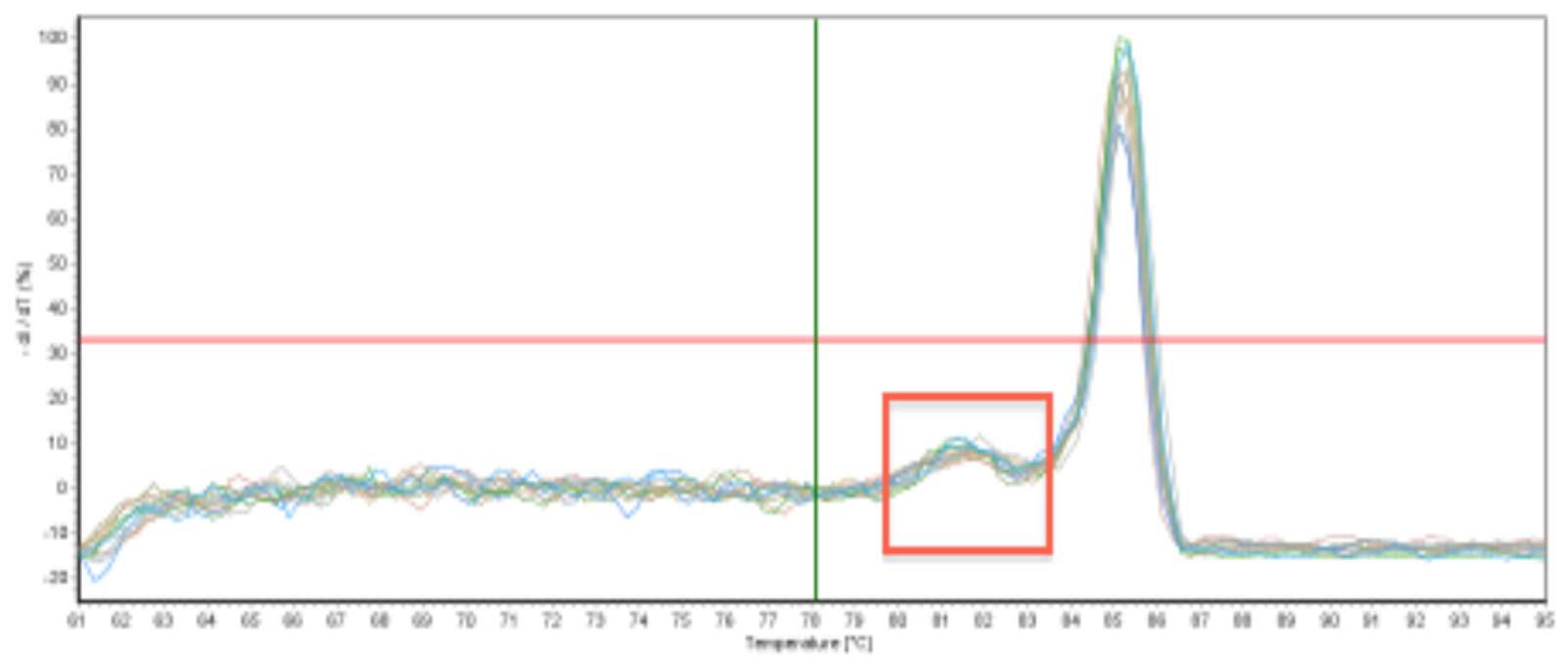

Thestodt. $39 \%$

Abb. 11: Beispiel für ein Primer-Dimer bei einer Schmelzkurvenanalyse (Runx2)

\subsection{2 mRNA-Analytik: relative Quantifizierung}

Die Quantifizierung einer Zielsequenz kann im Rahmen der real-time (RT)-PCR absolut oder relativ erfolgen. Bei der absoluten Quantifizierung wird in einer bestimmten Probe die Anzahl der Startkopien bestimmt. Oft ist jedoch eine solche Quantifizierung nicht zielführend, da von der Probenaufarbeitung bis hin zur cDNA viele Faktoren die Aussage verfälschen können. Die Anzahl der Startkopien in einer Probe cDNA hängt beispielsweise von der Größe der Gewebeprobe ab, aus der die cDNA synthetisiert wurde. Andere Faktoren beeinflussen ebenfalls die Menge an cDNA, die letztendlich in die PCR eingesetzt wird: die Gewebeproben werden verschieden gelagert, die RNA-Isolierung und die Reverse Transkription gelingen bei verschiedenen Proben nie mit exakt derselben Effizienz (Holodniy 1999).

Um dennoch ein Maß für die Kopienzahl pro Zelle zu erhalten, erfolgt der Bezug auf das Housekeeping-Gen als endogene Kontrolle. Hierbei wird zunächst lediglich die Existenz eines solchen Housekeeping-Gens postuliert, welches in allen betrachteten Proben konstant exprimiert ist, dessen RNA also in jeder Zelle in einer konstanten Kopienzahl vorliegt. Unter der zusätzlichen Annahme, dass die Einflussfaktoren der Probenaufarbeitung in gleicher Weise auf Zielgen und Housekeeping-Gen wirken, stellt der Quotient aus beiden das gewünschte Maß für die Kopienzahl des Zielgens pro Zelle dar. 
Ein zuverlässiger quantitativer Nachweis setzt nun eine funktionierende mRNAAnalytik voraus, welche bei hoher Genauigkeit und Reproduzierbarkeit exakte mRNA-Quantifizierungsergebnisse liefert (Pfaffl 2001). Um diesen Anforderungen nachzukommen, erfolgte die Normalisierung der RT-PCR-Ergebnisse nach den Postulaten des „effizienz-korrigierten relativen Quantifizierungsmodells“ von Pfaffl (2001).

\subsubsection{Normalisierung der real-time-Expressionsergebnisse mittels Beta2Mikroglobulin ( $\beta 2 \mathrm{M})$}

Bei der relativen Quantifizierung wird die Expression eines Zielgens mit der eines Referenzgens (Housekeeping-Gen) normalisiert, d.h. die Expression des zu untersuchenden Gens wird auf ein unreguliertes Housekeeping-Gen bezogen. Um die Normalisierung und die relative Quantifizierung mit diesem Gen durchführen zu können, müssen einige Bedingungen erfüllt sein. Als Housekeeping-Gene werden solche Gene bezeichnet, die ubiquitär und konstant exprimiert werden. Sie codieren für Proteine, die für die Zellfunktion, Zellentwicklung, Zellstruktur und Aufrechterhaltung des Zellstoffwechsels von Bedeutung sind. Für die Versuche dieser Arbeit wurde $\beta 2 \mathrm{M}$ als Housekeeping-Gen benutzt.

ß2M ist ein unglykolysiertes Protein, welches sich auf allen Zellen mit Zellkern befindet. Es bildet eine kleine Untereinheit des major histocompatibility complex I Moleküls (MHC I) auf der Zelloberfläche. Seine Funktion besteht darin, mit der Tertiärstruktur der MHC I $\alpha$-Kette zu interagieren und sie zu stabilisieren, damit diese Peptide den (CD8+) T-Lymphozyten präsentieren kann (Zhu et al. 2009).

In beiden Geweben, sowohl im gesunden als auch im parodontitisch erkrankten, wurde ß2M exprimiert. Die Verwendung von Referenzgenen wird in der Literatur kontrovers diskutiert (Sullivan et al. 2005, Gilsbach et al. 2006, Sellars et al. 2007), was vor allem durch technische Verbesserungen in der mRNA-Analytik und mRNAQuantifizierung bedingt ist. Zur optimalen Quantifizierung der Ergebnisse ist jedoch die Normalisierung über Housekeeping-Gene unerlässlich, weshalb die Auswahl und Verwendung eines Housekeeping-Gens kritisch geprüft werden sollte (Dheda et al. 2004, Bustin und Nolan 2004). 


\subsubsection{Berechnungen der Ratio}

Durch die Berechnung des Expressionsunterschiedes, der sogenannten Ratio, wird ein Vergleich der verschiedenen Proben überhaupt erst möglich. Der Berechnung des relativen Expressionsunterschiedes zwischen der parodontitisch erkrankten und der gesunden Referenzprobe, normalisiert durch das Referenzgen $ß 2 \mathrm{M}$, liegt die arithmetische Formel $E^{-\Delta \Delta c}$ ( $E$ entspricht der Effizienz der PCR) zugrunde (Pfaffl 2001).

Daraus ist folgendes Berechnungsmodell weiterentwickelt worden:

Ratio $=\frac{\left(E_{\text {Zielgen }}\right)^{\Delta C P_{\text {Zielgen }}(\text { Kontrolle-Behandlung })}}{\left(E_{\text {Referenzgen }}\right)^{\Delta C P_{\text {Referengen }}(\text { Kontrolle-Behandlung })}}$

ß2M wurde als Referenzgen verwendet. Für $ß 2 \mathrm{M}$ wurde eine Effizienz von 2 angenommen ( $\left.E_{\text {Referenzgen }}\right)$, ebenso für die Effizienz des Zielgens $\left(E_{\text {Zielgen }}\right)$. Die Werte der Gewebeproben der drei gesunden und der drei parodontitisch erkrankten Patienten wurden jeweils gemittelt.

Die auf diese Weise normalisierten Genexpressionswerte sind in Tabelle 10 aufgeführt. Eine Bewertung erfolgt nach den Kriterien I (Increased), D (Decreased) und NC (No Change). Gene mit einer mindestens zweifach niedrigeren Signalintensität (fold change Ratio - 2) wurden als reguliert definiert.

Die Marker CD13, CD29 und CD44 weisen in den real-time (RT)-PCRUntersuchungen eine unveränderte Genexpression im Vergleich zum gesunden Gewebe auf, die Ratios lagen hier bei 0,624 (CD13), 0,608 (CD29) und 0,619 (CD44). Für CD73 kann mit einer Ratio von 0,645 im parodontitisch erkrankten Gewebe ebenfalls ein gleichbleibendes Expressionslevel nachgewiesen werden.

Aus der großen Gruppe der Kollagene wurde Kollagen Typ I (Col I) untersucht. Col I weist im parodontitisch erkrankten Gewebe eine im Vergleich zum gesunden dreifach niedrigere Expression auf (Ratio 0,323). Runx2 zeigt im erkrankten Gewebe ebenfalls eine um einen sehr ähnlichen Faktor verminderte Genexpression (Ratio $0,315)$. 
0

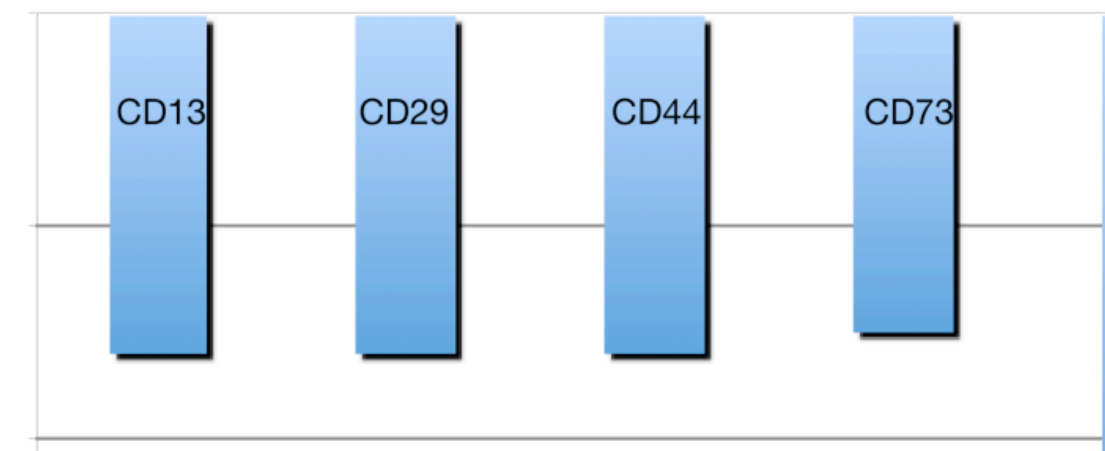

$-2$

$-3$

$-4$

Abb. 12: Veränderungen der Expression verschiedener Gene im parodontitisch erkrankten gegenüber dem gesunden Gewebe

\begin{tabular}{|c|c|c|c|c|}
\hline Denotation & Transcript & Accession nr. & $\begin{array}{c}\text { Ratio } \\
\text { Parodontitis }\end{array}$ & Fold Change \\
\hline CD13 & Aminopeptidase $\mathrm{N}$ & BC058928 & 0,624 & $\mathrm{NC}$ \\
\hline CD29 & Integrin beta1 & BC020057 & 0,608 & $\mathrm{NC}$ \\
\hline CD44 & $\begin{array}{l}\text { Class III extracellular } \\
\text { matrix receptor }\end{array}$ & NM_000610 & 0,619 & $\mathrm{NC}$ \\
\hline CD73 & Ecto-5'-Nucleotidase & NM_002526 & 0,645 & $\mathrm{NC}$ \\
\hline Coll & Kollagen Typ I & NM_000088 & 0,323 & $\mathrm{D}$ \\
\hline Runx2 & $\begin{array}{l}\text { runt related } \\
\text { transcription factor }\end{array}$ & NM_004348 & 0,315 & $\mathrm{D}$ \\
\hline
\end{tabular}

Tab. 10: Darstellung der Expression in der real-time (RT)-PCR

Aus den Daten der "Ratio Parodontitis" ergibt sich ein Mittelwert von 0,522 und eine Standardabweichung von 0,14. Die durch das „effizienz-korrigierte relative Quantifizierungsmodell“ von Pfaffl (2001) gewonnenen Daten machen die relativen Expressionsunterschiede zwischen gesundem und erkranktem Gewebe deutlich (Abb.12). 


\subsection{Ergebnisse der FACS-Analysen}

\subsubsection{Auswertung der Proben}

Die Datenanalyse erfolgte mit dem Programm WinMDI Version 2.9 - Windows 3.95 (Microsoft Deutschland GmbH, Unterschleißheim). Die Darstellung der gemessenen Signale erfolgt dabei als zweidimensionales sog. Dot-Plot-Fenster, in dem jedes Ereignis, z.B. eine Zelle oder Zelltrümmer, als einzelner Punkt dargestellt wird und so entsprechend seiner Fluoreszenz und Größe bzw. Granularität repräsentiert wird. Aufgetragen ist hier die Phycoerythrin (PE)-Fluoreszenz (FL2) gegenüber der Fluorescein-Isothiocyanat (FITC)-Fluoreszenz (FL1). Das Punktdiagramm ist in vier Quadranten aufgeteilt, in denen die Zellen in Abhängigkeit von ihren Zelleigenschaften bzw. ihrer relativen Fluoreszenz erscheinen. Es ist zu bedenken, dass Zellen, die exakt die gleichen Fluoreszenzeigenschaften aufweisen, auch nur als ein Punkt dargestellt werden. Dot-Plots geben daher nicht die absolute Zellzahl wieder.

\subsubsection{Ergebnisse der flow-zytometrischen Analyse der spezifischen} Oberflächenantigene der Zellen und deren statistische Auswertung

War eine ausreichende Konfluenz der Zellen in der Kultur erreicht, wurden sie geerntet und standen zur weiteren Untersuchung ihrer Oberflächenantigene mittels FACS zur Verfügung.

Im Folgenden sind die Ergebnisse der flow-zytometrischen Analysen nur zweier Gewebeproben (GES47: Zellen gesunden Parodontiums, PAR33: Zellen parodontitisch erkrankten Parodontiums) in Bildtafeln dargestellt. Ebenfalls mittels FACS untersucht und statistisch ausgewertet wurden jeweils drei Zelllinien aus gesundem und parodontitisch erkranktem Parodont, deren Ergebnisse durch die gezeigten Bildtafeln repräsentiert werden. Diese insgesamt sechs Zelllinien sind auch zur Genexpressionsanalyse mittels real-time (RT)-PCR herangezogen worden.

Im Anschluss an die Dot Plots werden Box Plots der Rohdaten dargestellt (Stichprobenumfang $n=3$ ), aufgeteilt nach den Gruppen „gesund“, d.h. parodontal gesundes PDL-Gewebe, und „krank“, parodontal erkranktes PDL-Gewebe. 
Mit Hilfe des t-Tests für zwei unabhängige Stichproben wurden die gewonnenen Ergebnisse auf statistisch signifikante Unterschiede hinsichtlich der Expression der verschiedenen Antigene überprüft. Bei $p \leq 0,01$ liegt statistisch ein hochsignifikanter Unterschied in der Expression vor und bei $p \leq 0,05$ ein signifikanter Unterschied. Ist $p>0,05$, so ist der Unterschied in der Expression des jeweiligen Antigens zwischen gesundem und parodontal erkranktem PDL-Gewebe statistisch nicht signifikant.

\subsubsection{Auswertung der flow-zytometrischen Analyse und Statistik der Zellen aus gesundem und parodontitisch erkranktem Gewebe im Hinblick auf die Oberflächenantigene CD29 und CD44}

Die Fluoreszenz ist bei Zellen aus gesundem und erkranktem Gewebe hinsichtlich CD29 und CD44 sehr ähnlich. Der prozentuale Anteil der CD29-positiven Zellen an den insgesamt gemessenen Zellen lag im gesunden bei 99,53\% und im erkrankten bei 97,73\% (CD29). Beide Gewebe zeigten nahezu keine CD44-positiven Zellen. Im gesunden Gewebe waren es 0,01\% und im erkrankten 0,09\%.

A

GES47 neg K

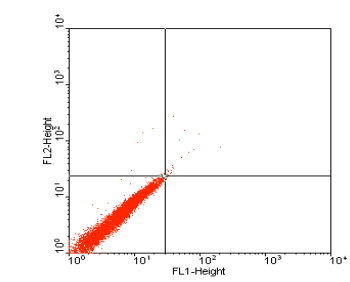

GES

PAR33 neg $K$

PAR

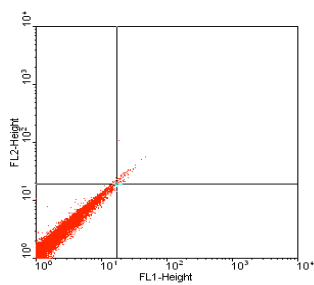

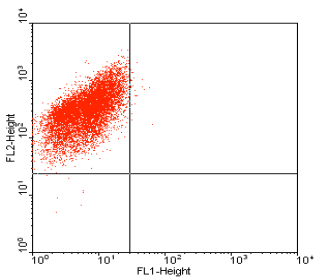

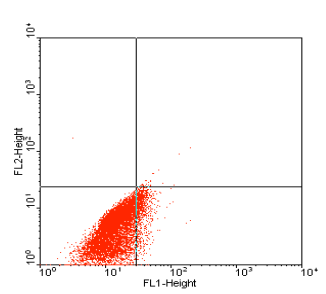

$33 \mathrm{CD} 29(97,73)$

$33 \operatorname{CD} 44(0,09)$

B $47 \operatorname{CD} 29(99,53)$

$47 \operatorname{CD} 44(0,01)$
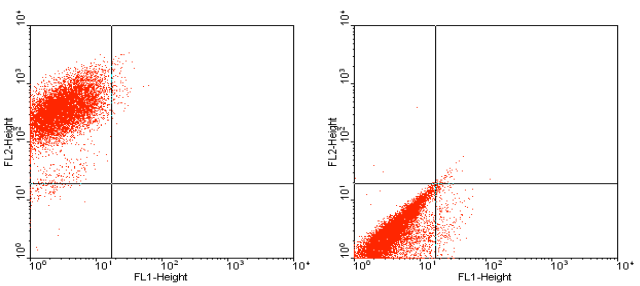

Bildtafel 1: Vergleich zwischen gesundem (exemplarisch GES47) und erkranktem (exemplarisch PAR33) Gewebe, A: Negativkontrollen, B: Expression von CD29, C: Expression von CD44 


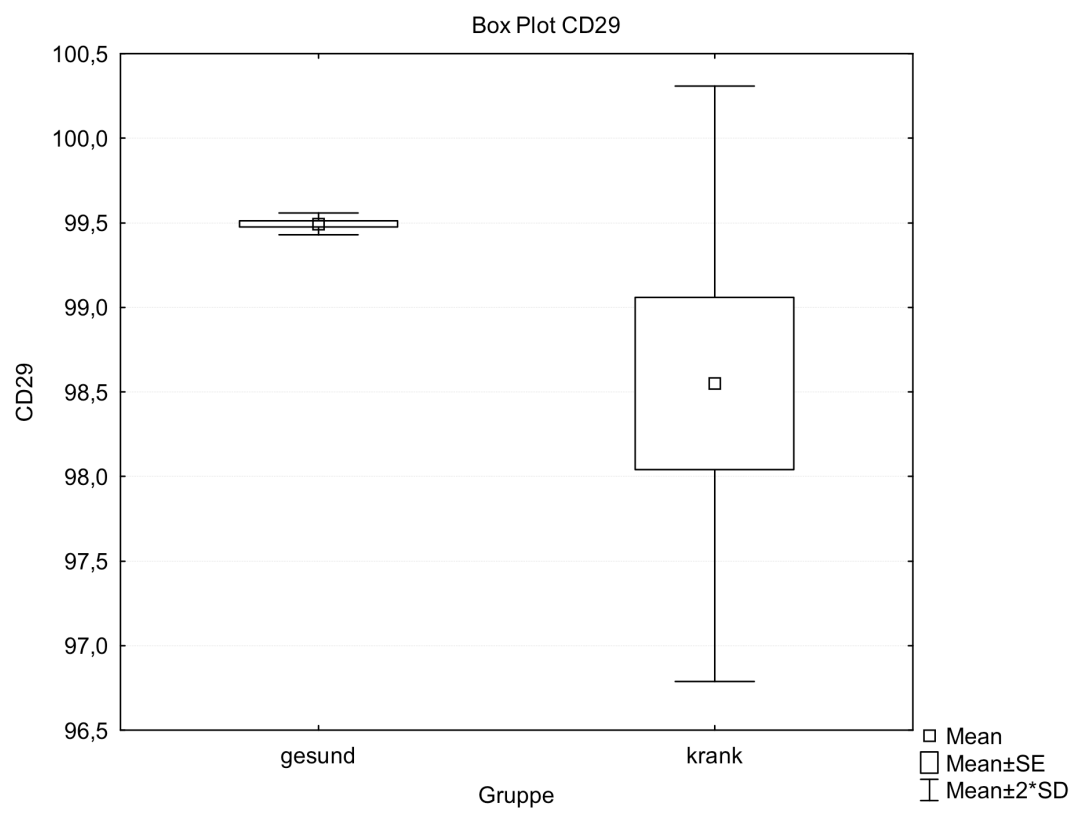

Abb. 13: Box-Plot-Darstellung der Expression von CD29 in gesundem und parodontitisch erkranktem PDL-Gewebe

Der Mittelwert für CD29 beträgt bei gesunden Proben 99,49 und für erkrankte Proben 98,55. Die Standardabweichung liegt bei 0,026 bzw. bei 0,719. Zwischen beiden Proben besteht im FACS hinsichtlich der Expression von CD29 mit $p>0,05$ kein statistisch signifikanter Unterschied ( $p$-Wert: 0,14, t-Test).

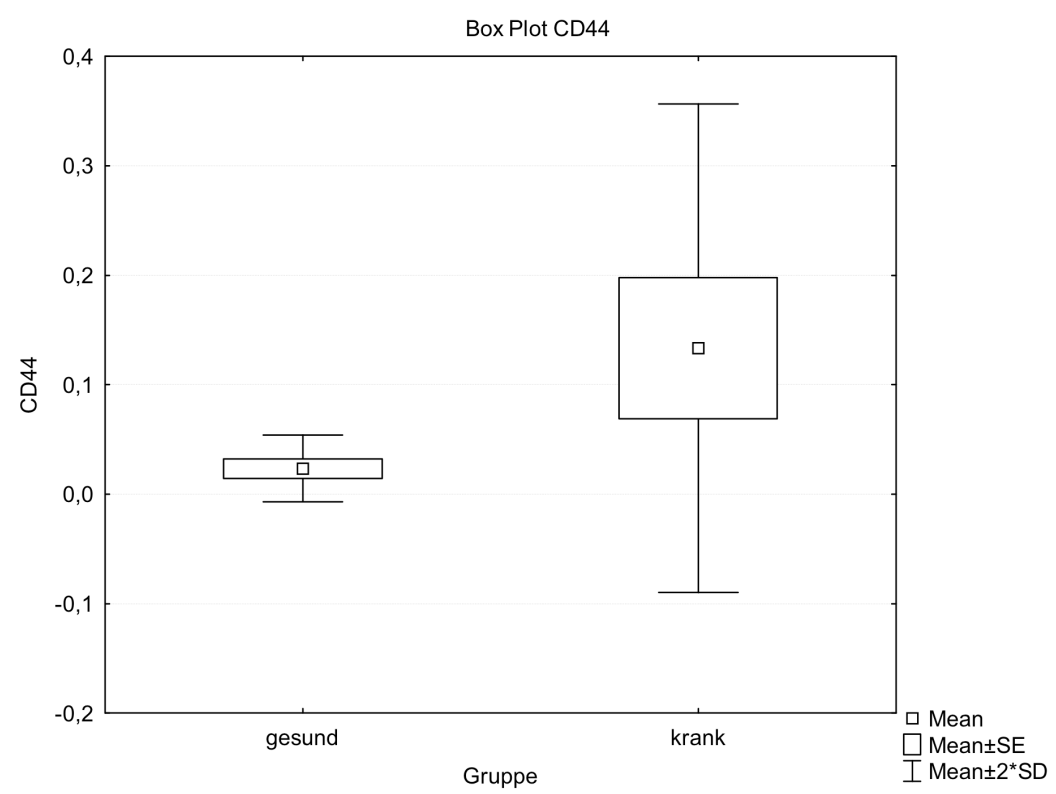

Abb. 14: Box-Plot-Darstellung der Expression von CD44 in gesundem und parodontitisch erkranktem PDL-Gewebe

Der Mittelwert für CD44 liegt für gesunde PDL-Proben bei 0,023 und für parodontitisch erkrankte Proben bei 0,133. Die Standardabweichung beträgt 0,012 
bzw. 0,091. Zwischen den gesunden und erkrankten Proben besteht im FACS hinsichtlich der Expression von CD44 mit p>0,05 kein statistisch signifikanter Unterschied (p-Wert: 0,17, t-Test).

\subsubsection{Auswertung der flow-zytometrischen Analyse und Statistik der Zellen aus gesundem und parodontitisch erkranktem Gewebe im Hinblick auf die Oberflächenantigene CD73 und CD13}

Der prozentuale CD73-positive Anteil der Zellen liegt im gesunden Gewebe bei 99,32\%. Im parodontitisch erkrankten Gewebe findet sich mit 66,9\% ein deutlich geringerer Anteil an CD73-positiven Zellen. Der prozentuale Anteil der CD13positiven Zellen an den insgesamt gemessenen Zellen lag im gesunden Gewebe bei $98,66 \%$ und im erkrankten bei $99,02 \%$.

A

GES47 neg K

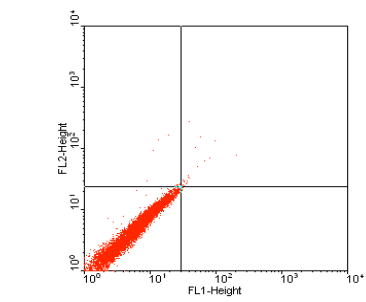

GES

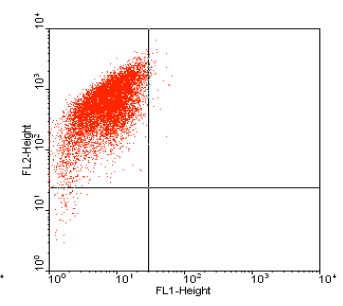

PAR33 neg $K$

PAR

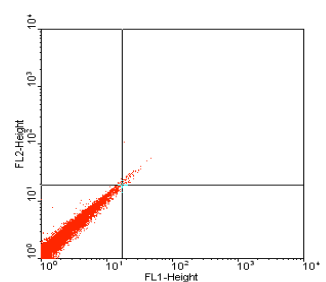

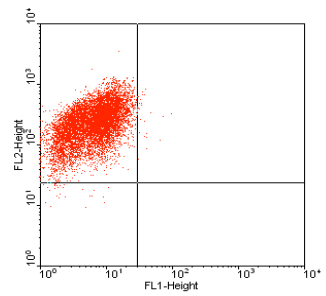

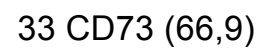

$33 \operatorname{CD} 13(99,02)$

B

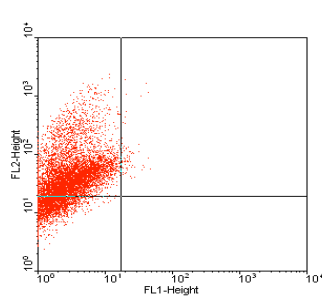

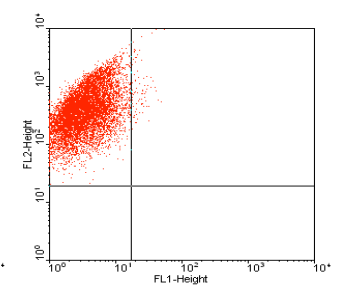

Bildtafel 2: Vergleich zwischen gesundem (exemplarisch GES47) und erkranktem (exemplarisch PAR33) Gewebe, A: Negativkontrollen, B: Expression von CD73, C: Expression von CD13 


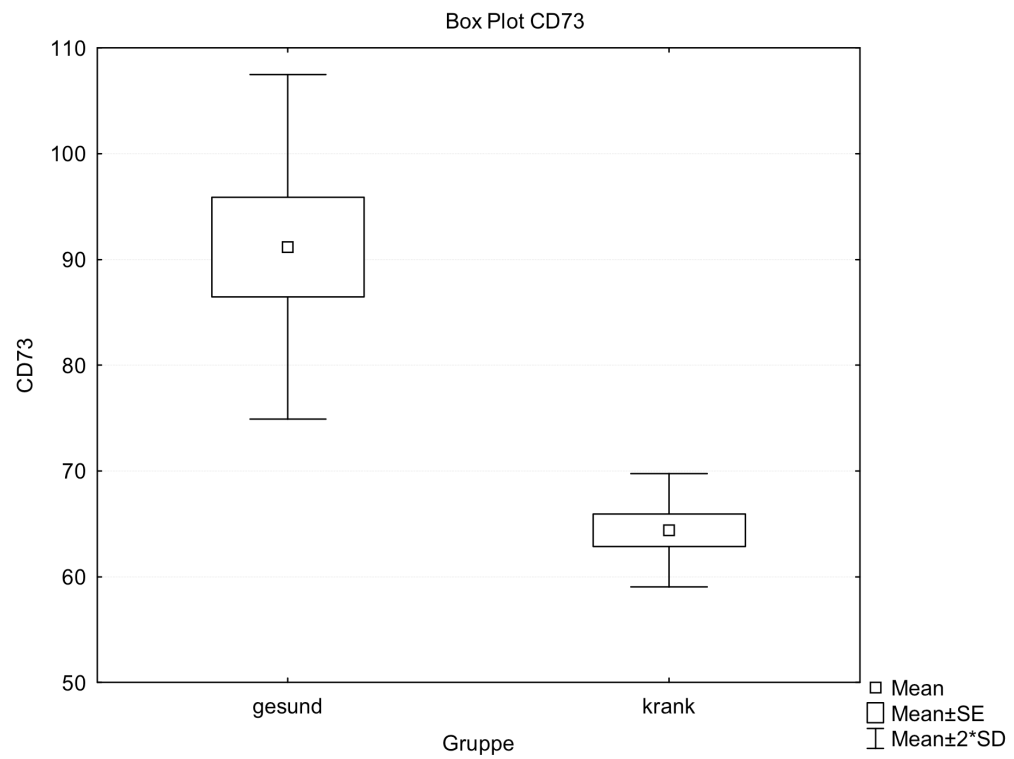

Abb. 15: Box-Plot-Darstellung der Expression von CD73 in gesundem und parodontitisch erkranktem PDL-Gewebe

Der Mittelwert für CD73 liegt für gesunde PDL-Proben bei 91,18 und für parodontitisch erkrankte Proben bei 64,38. Die Standardabweichung beträgt 6,65 bzw. 2,19. Die Expression von CD73 ist mit $p<0,01$ in den gesunden PDL-Proben hochsignifikant höher als in den erkrankten Proben ( $p$-Wert: 0,006, t-Test).

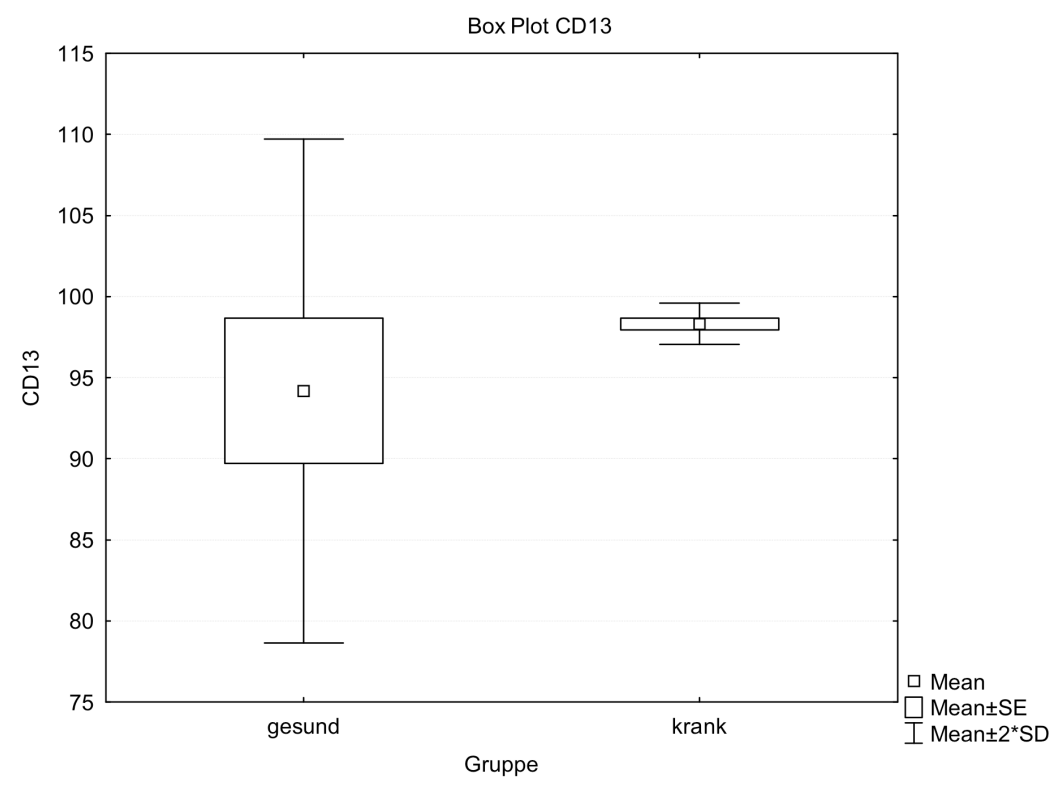

Abb. 16: Box-Plot-Darstellung der Expression von CD13 in gesundem und parodontitisch erkranktem PDL-Gewebe

Der Mittelwert für CD13 liegt für gesunde PDL-Proben bei 94,19 und für parodontitisch erkrankte Proben bei 98,32. Die Standardabweichung beträgt 6,34 
bzw. 0,52. Der Unterschied in der Expression von CD73 ist mit $p>0,05$ zwischen den gesunden und erkrankten PDL-Proben nicht signifikant ( $p$-Wert: 0,41, t-Test).

3.2.2.3 Auswertung der intrazellulären flow-zytometrischen Analyse und Statistik der Zellen aus gesundem und parodontitisch erkranktem Gewebe im Hinblick auf Kollagen Typ I (Col I)

Der Anteil an Col I-positiven Zellen an den insgesamt gemessenen Zellen liegt im gesunden Gewebe bei $59,69 \%$ und im parodontitisch erkrankten Gewebe bei $45,35 \%$.
A
B

GES neg K $\quad 47$ Col I $(59,69)$

GES
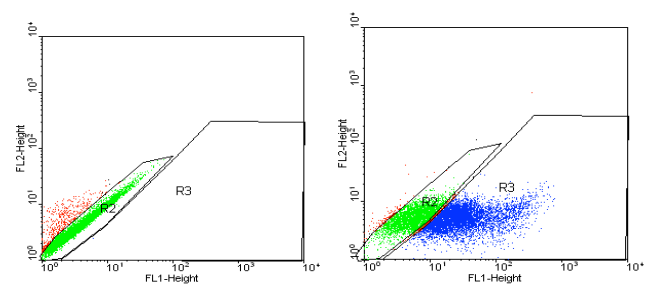

PAR neg $\mathrm{K}$

33 Col I $(45,35)$

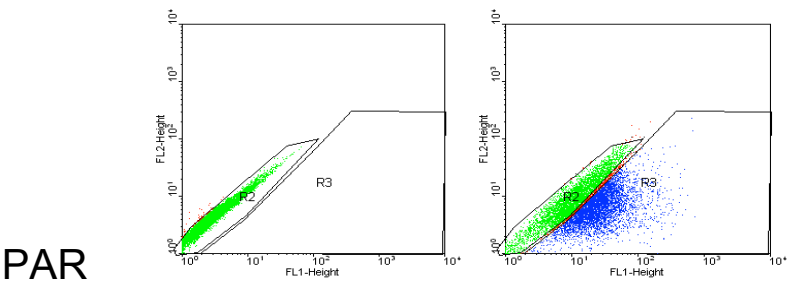

Bildtafel 3: Vergleich zwischen gesundem (exemplarisch GES47) und erkranktem (exemplarisch PAR33) Gewebe, A: Negativkontrollen, B: Expression von Kollagen Typ I 


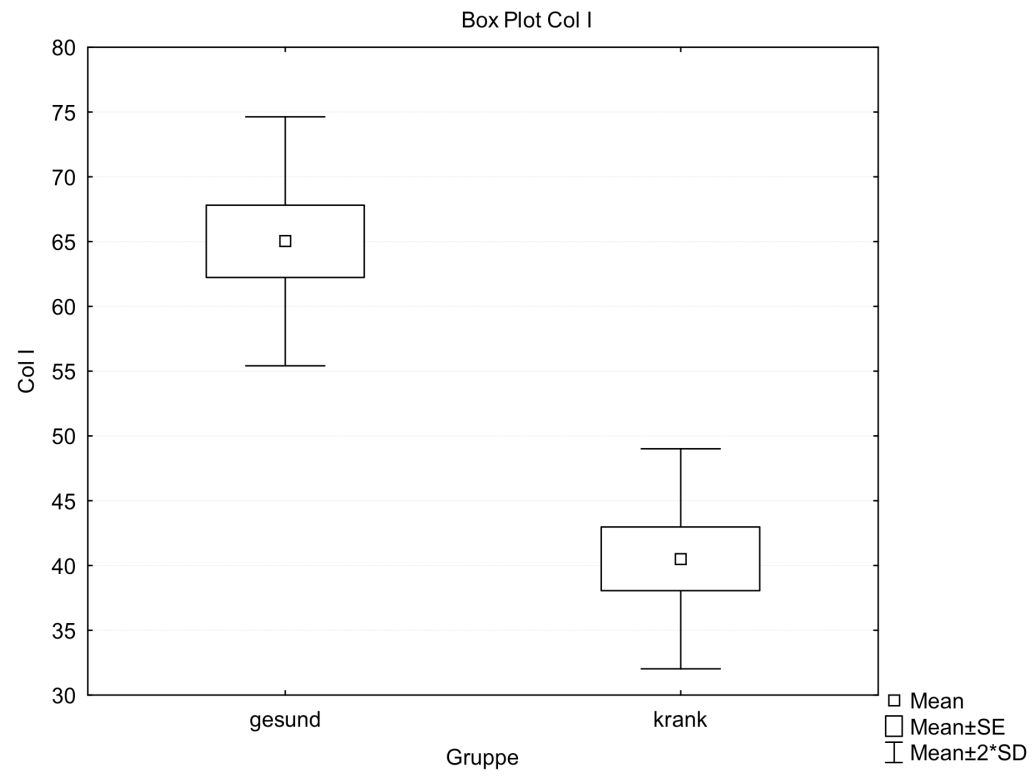

Abb. 17: Box-Plot-Darstellung der Expression von Kollagen Typ I in gesundem und parodontitisch erkranktem PDL-Gewebe

Der Mittelwert für Kollagen Typ I liegt für gesunde Proben bei 65,03 und für parodontitisch erkrankte Proben bei 40,52. Die Standardabweichung beträgt 3,92 bzw. 3,46. Die Expression von Kollagen Typ I ist mit $p<0,01$ in den gesunden PDLProben statistisch hochsignifikant höher als in den erkrankten Proben ( $p$-Wert: 0,003, $\mathrm{t}$-Test). 
3.2.2.4 Auswertung der intrazellulären flow-zytometrischen Analyse und Statistik der Zellen aus gesundem und parodontitisch erkranktem Gewebe im Hinblick auf Runx2

Der Anteil an Runx2-positiven Zellen liegt im gesunden Gewebe bei $13,53 \%$ und im parodontitisch erkrankten Gewebe bei $26,2 \%$.

A

GES neg K

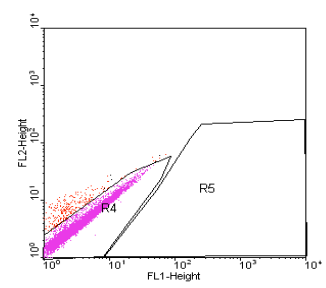

GES

PAR neg $K$

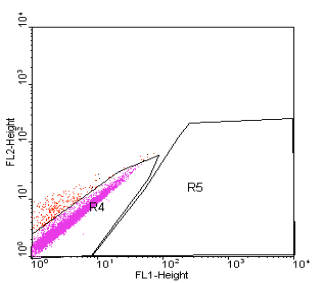

PAR
B

47 Runx2 $(13,53)$

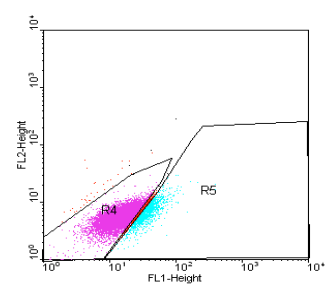

33 Runx2 $(26,2)$

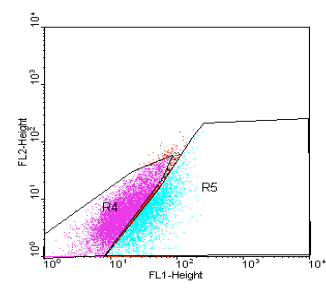

Bildtafel 4: Vergleich zwischen gesundem (exemplarisch GES47) und erkranktem (exemplarisch PAR33) Gewebe, A: Negativkontrollen, B: Expression von Runx2 


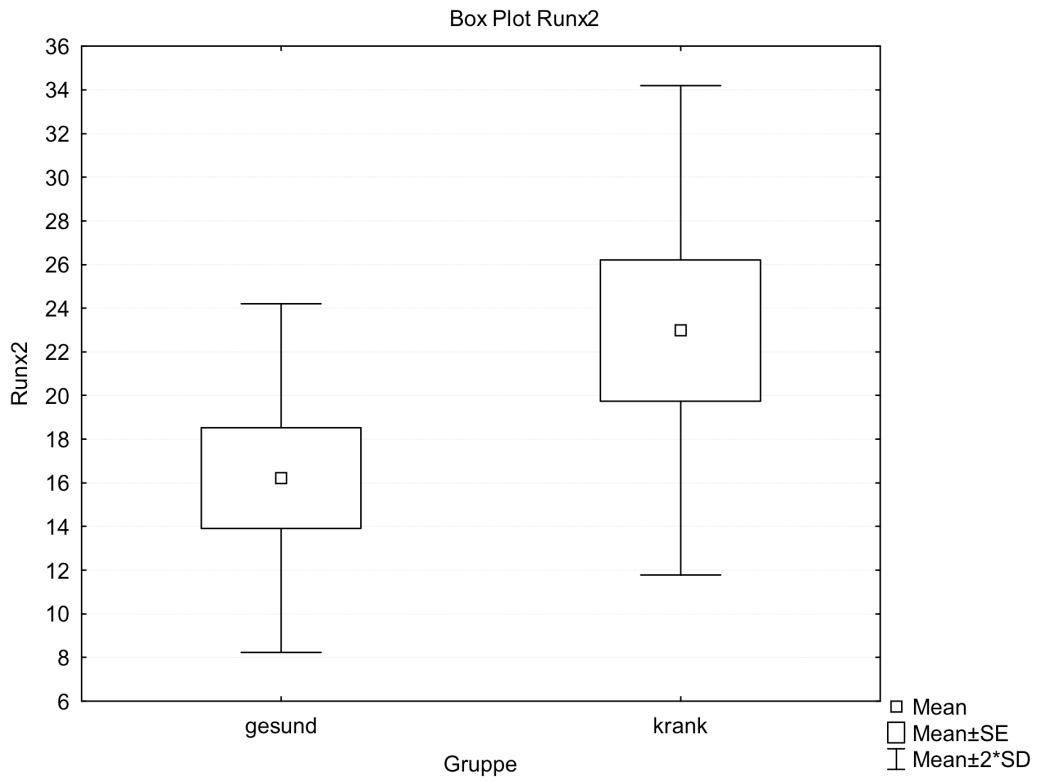

Abb. 18: Box-Plot-Darstellung der Expression von Runx2 in gesundem und parodontitisch erkranktem PDL-Gewebe

Der Mittelwert für Runx2 liegt für gesunde Proben bei 16,22 und für parodontitisch erkrankte Proben bei 22,98. Die Standardabweichung beträgt 3,25 bzw. 4,57. Zwischen den gesunden und erkrankten Proben besteht im FACS hinsichtlich der Expression von Runx2 mit $p>0,05$ kein statistisch signifikanter Unterschied ( $p$-Wert: $0,16, \mathrm{t}-$ Test). 


\begin{tabular}{|l|c|c|}
\hline & $\begin{array}{c}\text { GES 47 } \\
(\%)\end{array}$ & $\begin{array}{c}\text { PAR 33 } \\
(\%)\end{array}$ \\
\hline CD13 & 98,66 & 99,02 \\
\hline CD29 & 99,53 & 97,73 \\
\hline CD44 & 0,01 & 0,09 \\
\hline CD73 & 99,32 & 66,9 \\
\hline Col I & 59,69 & 45,35 \\
\hline Runx2 & 13,53 & 26,2 \\
\hline
\end{tabular}

Tab. 11: Tabellarische Übersicht der prozentualen positiven Expression eines Antigens im FACS, PAR entspricht den Zellen parodontitisch erkrankten Gewebes (PAR33), GES entspricht den Zellen gesunden Gewebes (GES47) 


\section{Diskussion}

Neben der Karies ist die Parodontitis der Hauptfaktor für den Verlust von Zähnen. Mit zunehmendem Alter und der gleichzeitigen Abnahme der manuellen Geschicklichkeit bei der täglichen Mundhygiene stellt die Parodontitis (in den meisten Fällen die chronische Form) sogar noch vor der Karies den Hauptgrund für das Lückengebiss dar (Micheelis und Schiffner, Vierte Deutsche Mundgesundheitsstudie DMS IV, 2006).

Innerhalb unserer Forschungsgruppe wurde mittels vergleichender MicroarrayAnalysen festgestellt, dass die Expression einiger Gene durch die parodontale Entzündung signifikant verändert ist. Vor diesem Hintergrund entstand der Gedanke, eine ex-vivo-Zellkultur aus gesunden und erkrankten PDL-Zellen zu entwickeln und ihre Unterschiede in der Genexpression mit den Methoden der real-time (RT)-PCR und des Fluorescence Activated Cell Sorting (FACS) weiter zu analysieren. Die Arbeitshypothese war, dass die spezifischen Charakteristika in der Zellkultur mit steigender Passageanzahl abnehmen bzw. sich die primär erkrankten Zellen in ihren Charakteristika gesunden Zellen wieder angleichen, da hier auf Dauer der inflammatorische Reiz fehlt.

Unter Zuhilfenahme von Genexpressionsanalysen wie z.B. der real-time (RT)-PCR oder Analysen auf der Protein-Ebene wie z.B. das FACS können zum einen die Gene bzw. Proteine erfasst werden, die wegen ihrer differentiellen Expression einen wichtigen Anteil an der Auflösung der EZM und am Abbau des Knochens haben, was wiederum den Zahnverlust zur Folge hat (Page und Schroeder 1976). Zum anderen können auch jene Stammzellen identifiziert werden, denen bei der Regeneration des Parodontiums womöglich eine große Bedeutung zugeschrieben werden kann (Huang et al. 2009, Shi et al. 2005, Zhou et al. 2008). Das Entzündungsgeschehen und ggf. auch seine Regenerationsvorgänge können auf molekularbiologischer Ebene besser verstanden werden und die Gene, die in ihrer Genexpression signifikant verändert sind, können Gegenstand weiterer zukunftsweisender Arbeiten sein. Vor diesem Hintergrund ist auch die vorliegende Dissertation entstanden. Sie soll mithilfe der Methoden der real-time (RT)-PCR und des FACS verschiedene Veränderungen bei den Adhäsionsmolekülen, den Bestandteilen der EZM und bei den die Immunantwort modulierenden Faktoren der PDL-Zellen des gesunden und parodontitisch erkrankten Zahns darlegen. 


\subsection{Diskussion der Entwicklung der spezifischen Antibiose in der Zellkultur}

Für isolierte Zellen aus einem Organismus muss unter in-vitro-Bedingungen eine Umgebung geschaffen werden, die den Zellen die Proliferation, das Wachstum, die Differenzierung und die Ausübung ihrer typischen Zellfunktionen erlaubt. Essentielle Substanzen wie Hormone, zahlreiche für die Synthese von Proteinen benötigte Aminosäuren, anorganische Salze und weitere Substanzen wie z.B. Spurenelemente und Vitamine müssen von außen zugeführt werden. Abfallprodukte wie z.B. Metabolite müssen hingegen durch ein Puffersystem neutralisiert werden. Für das Fortbestehen der Zellen in der Kultur und um einer bakteriellen Kontamination vorzubeugen bzw. um sie zu beseitigen, sind Antibiotika erforderlich. In einer kontaminierten Zellkultur kann kein Zellwachstum stattfinden. Aus diesem Grund wurden kontaminierte Zellkulturen bisher vermieden. Der Großteil bisheriger Studien ist mit einer Zellkultur aus PDL-Zellen des gesunden Zahnhalteapparates durchgeführt worden (Zhou et al. 2008, Hirano et al. 1997, Washio et al. 2010, Nagatomo et al. 2006). Für Studien, in denen explantierte humane PDL-Zellen in Primärkultur verwendet und charakterisiert wurden, wurden diese meistens dem parodontal gesunden Parodontium entnommen und in Kultur sekundär inflammatorischen Noxen wie bspw. Nikotin (James et al. 1999) oder IL-1 beta (Hirano et al. 1997, Deschner et al. 2000) ausgesetzt.

Das angestrebte Ziel, per se erkrankte und damit infizierte, kontaminierte humane Zellen für die Zellkultur zu gewinnen und in Kultur zu expandieren, machte die Entwicklung einer innovativen und spezifischen Antibiose erforderlich. Zunächst musste dafür ein „Austarieren“ der benötigten jeweiligen Konzentrationen stattfinden: Eine gewisse Kontamination sollte als fortwährender Einfluss einer polymikrobiellen, parodontopathogenen Infektion aufrechterhalten bleiben, um die Situation der Parodontitis in vivo möglichst genau nachzuempfinden. Diese Balance in der Konzentration zwischen eingeschränkter Zellproliferation bis zur Elimination aufgrund einer Intoxikation und der bakteriellen Überwucherung galt es zu entwickeln. Die Aminoglykoside Streptomycin und Gentamycin werden konventionell in der Zellkultur eingesetzt und fanden daher zunächst auch im Rahmen der Versuche für die vorliegende Arbeit Verwendung. Das Wirkungsspektrum von Strepto- und Gentamycin richtet sich gegen grampositive und gramnegative Bakterien. Neben dem breiten Wirkungsspektrum und der bakteriziden Wirkung ist der rasche Wirkungseintritt als Vorteil zu nennen. Haben sie die Poren und die 
Lipopolysaccharid-Doppelschicht der Bakterien einmal durchdrungen, binden sie an die Ribosomen, und es können nur noch funktionsuntüchtige Proteine synthetisiert werden. Das Bakterium ist nicht länger lebensfähig. Ein großer Nachteil von Streptound Gentamycin ist jedoch, dass alle Anaerobier, und damit auch Porphyromonas gingivalis (P.g.) und Tannerella forsythensis (T.f.) als wesentliche Leitkeime der Parodontitis, gegenüber den Aminoglykosiden resistent sind. Mit Streptomycin konnte der bakteriellen Kontamination nicht wirksam begegnet werden. Die Arbeitsgruppe um Miyata et al. (1997) stellte fest, dass durch Streptomycin die proinflammatorische Funktion von P.g. nicht signifikant beeinflusst wird. Das jedoch muss gewährleistet sein, da mit P.g. gerade die anaerobe gramnegative Flora in aktiven Taschen bei der Parodontitis vertreten ist (Newman et al. 1973).

Bereits in den späten 1920er Jahren wurden potente antibakterielle Substanzen wie die Sulfonamide und das Penicillin entdeckt und schon bald in der Therapie der Parodontitis eingesetzt (Williams 2008). Das Penicillin fand sich als Zusatz in Mundspüllösungen (Strock 1944) und wurde außerdem per os systemisch verabreicht (Schuessler et al. 1945). Die klinische Wirkung auf die nekrotisierende Gingivitis innerhalb von 6 bis 24 Stunden verschaffte dem Penicillin seine Bedeutung für den Einsatz im Rahmen der Parodontitistherapie.

Im Jahre 1981 berichten Loesche et al. über den Einsatz von systemisch verabreichtem Metronidazol unterstützend zu dem mechanischen Debridement (Säuberung der Wurzeloberflächen). Sie erzielten damit sehr gute antimikrobielle Effekte (Loesche et al. 1981, Loesche et al. 1992, Haffajee et al. 2007). Da in der subgingivalen Flora jedoch nicht nur ein parodontopathogener Keim enthalten ist, sondern verschiedene Keime mit unterschiedlichen Virulenzfaktoren, gingen van Winkelhoff und Mitarbeiter dazu über, Metronidazol und das Penicillin Amoxicillin zu kombinieren (van Winkelhoff et al. 1989). Metronidazol ist ein Nitroimidazol, welches über DNA-Strangbrüche bakterizid wirkt. Der Wirkstoff richtet sich vornehmlich gegen anaerobe Keime wie z.B. P.g..

Amoxicillin ist ein $\beta$-Lactam-Antibiotikum, welches zellwandaufbauende Enzyme blockiert und so die Zytoplasmamembran der Bakterien zerstört. Die Penicilline sind wirksam gegen (fakultativ) aerobe grampositive Bakterienarten und gegen anaerobe gramnegative Stäbchen wie Aggregatibacter actinomycetemcomitans. Feres et al. beschreiben 2001, dass Amoxicillin sehr wirksam gegen die speziellen parodontopathogenen Keime in der Parodontitis und als antibakterielles 
systemisches Therapeutikum geeignet ist.

Da sich die Kombination aus Metronidazol und Amoxicillin (Winkelhoff-Cocktail, van Winkelhoff et al. 1989) klinisch bei Patienten unterstützend in der Therapie der Parodontitis bewährt hat (de Graaff et al. 1989, Goené et al. 1990, Cionca et al. 2010), haben wir diese Kombination auch für unser Vorgehen in der ex-vivoZellkultur übernommen. Wird sie zu hoch dosiert, findet aufgrund der Zytotoxizität keine Zellproliferation mehr statt. In einer zu niedrigen Dosierung kommt es zu einer bakteriellen Überwucherung, was ebenfalls proliferationshemmend wirkt. Es wurden die Antibiotika in jeweils unterschiedlichen Konzentrationen miteinander kombiniert und der bakterielle Kontaminationsstatus mit dem Mikroskop (Zeiss Axiovert 40 CFL, Carl Zeiss Jena $\mathrm{GmbH}$, Jena) ausgewertet. Entsprechend diesem Status wurde die Antibiose modifiziert. Final hat sich eine Konzentration von $35 \mu \mathrm{g} / \mathrm{ml}$ Amoxicillin und $25 \mu \mathrm{g} / \mathrm{ml}$ Metronidazol bewährt.

\subsection{Diskussion von CD13 (Aminopeptidase N)}

Aminopeptidase $N(A P N) / C D 13$ ist ein Ektoenzym mit verschiedenen Funktionen. Das membrangebundene Glykoprotein ist u.a. beteiligt an antiinflammatorischen Reaktionen und kontrolliert Antworten des Immunsystems. CD13/APN ist ein weit verbreitetes Enzym, welches in zahlreichen Organen, Geweben und auf vielen Zelltypen wie z.B. Endothel- und Epithelzellen, Fibroblasten und Leukozyten vorkommt (Look et al. 1989, Luan und Xu 2007). Die Arbeitsgruppe um Kunii et al. (2005) hat herausgefunden, dass CD13 mit seiner Wirkung auf Interleukin-4 und Interleukin-8 zu der antiinflammatorischen Antwort in parodontalem Gewebe beiträgt (Kunii et al. 2005, Kanayama et al. 1995). Huang et al. (2009) und Trubiani et al. (2005) liefern mit ihren Ausführungen über den Fund von CD13-positiven Zellen aus dem parodontalen Ligament einen möglichen Hinweis auf mesenchymale Stammzellen. In unseren Untersuchungen fanden wir in dem gesunden Gewebe als auch in dem parodontitisch erkrankten Gewebe mittels FACS jeweils CD13-positive Zellen. Möglicherweise ist die auch unter entzündlichen Bedingungen weiter vorhandene Expression ein Hinweis auf regenerationsfördernde, mit stammzellähnlichen Eigenschaften versehene, erkrankte PDL-Zellen. Derzeit fehlen jedoch weitere Studien, welche die Expression von CD13 im parodontitisch erkrankten PDL untersuchen. 


\subsection{Diskussion von CD29 (Integrin Beta1)}

Die Integrine stellen eine Familie aus heterodimeren Zelloberflächen-Rezeptoren dar, welche aus einer alpha- und einer beta-Kette bestehen. Zellen werden mit der EZM über Integrine verbunden. Heterodimere des Integrin $\beta 1$ binden z.B. Kollagene, Laminine, Fibronectin oder Vitronectin (Brakebusch et al. 1997). Die Integrine vermitteln zudem Signale aus der EZM in die Zelle. Die Signale betreffen das Zellüberleben, die Zellproliferation, -differentation und -migration (Giancotti und Ruoslahti 1999, Hintermann und Quaranta 2004). Uitto et al. (1992) fanden heraus, dass auch die Adhäsion der Zellen untereinander durch die Integrine ermöglicht wird. In unseren Untersuchungen stellte sich sowohl in der real-time (RT)-PCR als auch mittels FACS kein Unterschied in der Expression von CD29 bei den Zellen des gesunden und des parodontitisch erkrankten Gewebes heraus. Sowohl Zellen gesunden als auch erkrankten PDLs exprimieren CD29. Dieses Ergebnis deckt sich mit dem der Arbeitsgruppe um Tasman et al. (2001), welche Zellen der Pulpa gesunder Zähne und solcher mit einer chronischen Parodontitis untersucht hat. Auch sie stellte hierbei fest, dass hinsichtlich der Expression von CD29 kein signifikanter Unterschied zwischen den Zellen beider Gewebe besteht. Allerdings ist es auch eher unwahrscheinlich, dass sich die chronische marginale Parodontitis auf das Expressionsmuster der Pulpazellen auswirkt. Veränderungen durch eine apikale Parodontitis verursacht durch Bakterien im Wurzelkanalsystem sind dagegen denkbar (Siqueira et al. 2009). Auch Gemmell et al. (1994) untersuchten, ob es Unterschiede im Expressionsmuster der Adhäsionsmoleküle von Zellen aus gesunden Proben und solchen Proben gibt, denen eine Parodontitis zugrunde lag. Es stellte sich per Immunoperoxidase-Technik heraus, dass auch hier Endothelzellen, Keratinozyten und Lymphozyten gleichermaßen CD29-positiv sind.

Durchgeführte Studien unserer Arbeitsgruppe (Szydlik 2009) mit der Untersuchungsmethode des Microarrays und explantiertem, parodontitisch erkrankten Gewebe lieferten jedoch das Ergebnis, dass das Integrin $\beta 1$ bei der chronischen Parodontitis herunterreguliert ist. Vermutlich ist es in der Phase der Zellkultur zu einer De-Differenzierung der Zellen gekommen, so dass sich die PDLZellen parodontitisch erkrankten Gewebes in ihren Eigenschaften denen des gesunden Gewebes angeglichen haben. 


\subsection{Diskussion von Kollagen Typ I (Col I)}

Der Hauptbestandteil der EZM ist das Kollagen Typ I. Die organische Matrix des Knochens wird zu 90\% durch das Kollagen Typ I aufgebaut und stellt mit $80 \%$ das am häufigsten im Zahnhalteapparat vorkommende Kollagen dar. Die PDL-Zellen nehmen einen sehr großen Einfluss auf die Regeneration der Strukturen im Parodontium (Nagatomo et al. 2006, Benatti et al. 2008, Molnár et al. 2008). Larjava et al. (1989) haben erarbeitet, dass je nach Gewebe (entzündliches Infiltrat und umliegendes Gewebe) die Fibroblasten bei der Parodontitis unterschiedlich viel Kollagen Typ I produzieren. Die im entzündlichen Infiltrat ansässigen Fibroblasten produzieren nur sehr geringe Mengen an Kollagen Typ I, während die Fibroblasten des umliegenden Gewebes aktiver sind und größere Mengen an Kollagen Typ I produzieren. Auch Page et al. (1997) machten deutlich, dass die Aufgabe der im gesunden Parodontium ansässigen Epithel- und Endothelzellen sowie Fibroblasten die Aufrechterhaltung der Homöostase ist. Diese Zellen können jedoch infolge eines bakteriellen Angriffs durch Lipopolysaccharide in der Zellwand der Bakterien ihrer Funktion beraubt werden. Sie tragen jetzt nicht mehr zur Homöostase bei, sondern sezernieren Zytokine wie z.B. Interleukin-1 und Prostaglandin $E_{2}$. Unter gesunden Bedingungen sind die Gene der Fibroblasten für verschiedene Kollagene und Inhibitoren von Matrixmetalloproteinasen aktiv und die Gene für Matrixmetalloproteinasen inaktiv. In einer aktiven Parodontitis jedoch sind in Fibroblasten die Gene für Kollagene abgeschaltet und solche für Matrixmetalloproteinasen eingeschaltet (Page et al. 1997). Auch Nanci und Somerman haben 1994 bereits beschrieben, dass Fibroblasten, welche die größte Population an Zellen im PDL darstellen, unter normalen Bedingungen u.a. Kollagenfibrillen synthetisieren. Den Fibroblasten kommt eine wichtige Rolle bei dem Turn-over, bei der Heilung und der Regeneration zu. Vollziehen sich Veränderungen im Bindegewebe, wie es z.B. bei bestehendem entzündlichen Reiz der Fall ist, sind die Fibroblasten hingegen fähig, Kollagen abzubauen und den Gewebeabbau auf diese Weise voranzutreiben (Ten Cate et al. 1976). Dieser seit längerem bekannte Hintergrund bestätigt unsere Ergebnisse, dass die Kollagenexpression in Zellen aus entzündlich verändertem PDL gegenüber Zellen gesunden PDLs vermindert ist. In unseren Untersuchungen mit der real-time (RT)-PCR haben wir eine um den Faktor 3 verminderte Expression des Kollagen Typ I in parodontal erkranktem Gewebe im Vergleich zum gesunden feststellen können. In den Untersuchungen mittels FACS 
sind sowohl in gesundem als auch im erkrankten Gewebe Kollagen-Typ- I- positive Zellen vorhanden, jedoch ist die Expression parodontitisch erkrankter PDL-Zellen hochsignifikant geringer. Dass der Anteil an Kollagen- Typ-I- positiven Zellen aus gesundem Gewebe bei auch nur durchschnittlich 65,03\% liegt, lässt sich mit einer während der Zellkultur erfolgten De-Differenzierung erklären.

Eine interessante Feststellung machte auch die Arbeitsgruppe um Benatti et al. (2008). Sie hat PDL-Zellen in einer Kultur über 28 Tage hinweg altern lassen und dadurch festgestellt, dass der mRNA-Expressionslevel von älteren Zellen bei Kollagen Tур I herunterreguliert ist. Aufgrund unserer erniedrigten Ergebnisse aus der real-time (RT)-PCR für die Proben aus dem parodontitisch erkrankten Gewebe könnte auch vermutet werden, dass es sich bei den Gewebeproben vermehrt um ältere PDL-Zellen handelt, bei denen also die Produktion von Kollagen Typ I herunterreguliert ist.

\subsection{Diskussion von runt related transcription factor (Runx2)}

Der runt related transcription factor ist ein osteoblasten-spezifischer Transkriptionsfaktor, d.h. er bindet an spezifische Sequenzen der DNA und reguliert auf diese Weise die Transkription verschiedener Gene. Er ist wichtig für die Differenzierung von pluripotenten mesenchymalen Zellen zu Osteoblasten (Ducy et al. 1997, Komori 2000), und er kontrolliert deren Proliferation und Aufrechterhaltung sowie die Knochenbildung (Camilleri und McDonald 2006). Runx2 ist einer der Transkriptionsfaktoren, der in vivo die Expression von Kollagen Typ I in Osteoblasten reguliert (Kern et al. 2001). Die Arbeitsgruppe um Banerjee et al. (2001) beschreibt, dass die Untergruppe Runx2-I in nicht-osteoblastären mesenchymalen Zellen, Osteoprogenitorzellen, Chondrocyten und Thymocyten während der frühen Osteoblastendifferenzierung kontinuierlich exprimiert wird. Die Expression der Untergruppe Runx2-II beschränkt sich auf Osteoblasten während ihrer Reifung und die enchondrale Knochenentwicklung (Schroeder et al. 2005). Darüber hinaus variieren die mRNA-Level während des Zellzyklus von Runx2 in osteoblastären Zellen, hohe Level sind in der G1-Phase, niedrige in der S-Phase und der Mitose festgestellt worden (Galindo et al. 2005). Die Level von Runx2 werden durch das Vitamin $D_{3}$ negativ beeinflusst und herunterreguliert (Drissi et al. 2002). Die Arbeitsgruppe um Liu et al. (2010) hat herausgefunden, dass die Level von Vitamin $D_{3}$ im Plasma und im Sulkusfluid bei Patienten mit einer aggressiven Parodontitis 
erhöht sind, sich jedoch durch die Initialbehandlung im Rahmen der ParodontitisTherapie senken lassen. Diese Tatsache legt die Vermutung nahe, dass Vitamin $D_{3}$ in das parodontale Entzündungsgeschehen involviert ist und vielleicht sogar von den entzündlich veränderten parodontalen Geweben produziert wird (Liu et al. 2010). Die Ergebnisse der vorliegenden Arbeit zeigen bei der real-time (RT)-PCR im parodontitisch erkrankten Gewebe gegenüber dem gesunden dreifach erniedrigte mRNA-Level von Runx2. Dieses Ergebnis aus der real-time (RT)-PCR könnte die Schlussfolgerung nahe legen, dass nicht nur bei der aggressiven Parodontitis, sondern auch bei der chronischen Form der Erkrankung die Level von Vitamin $D_{3}$ erhöht und dadurch die von Runx2 erniedrigt sind. Die Ergebnisse aus dem FACS zeigen für Runx2 bei Zellen gesunden und parodontitisch erkrankten PDLs hinsichtlich der Expression zwar keinen signifikanten Unterschied, der positive prozentuale Anteil von durchschnittlich 16,22 und 22,98\% zeigt jedoch, dass dieses Antigen nur mit verhältnismäßig geringem Expressionslevel vorliegt. Die Expressionslevel für parodontitisch erkrankte PDL-Zellen liegen tendenziell etwas höher. Denkbar als Erklärung für diese Ergebnisse ist, dass mit ansteigender Passageanzahl die mRNA-Expressionslevel von Runx2 herunterreguliert worden sind. Unterstützt wird diese Annahme durch die Erkenntisse von Itaya et al. (2009), die Veränderungen während der Zellkulturpassagen eins bis sechs bei gesunden PDL-Zellen untersucht haben. Auch sie konnten eine De-Differenzierung der Zellen mit steigender Passageanzahl feststellen. Der Einfluss des Passagierens auf die Expression von Runx2 könnte Gegenstand weiterer Untersuchungen sein, da hierzu derzeit noch Studien fehlen.

\subsection{Diskussion von CD44 (Hyaluronrezeptor)}

CD44 ist ein transmembranöses Glykoprotein. Der Rezeptor sitzt auf der Oberfläche von Fibroblasten und Epithelzellen des PDLs und der Gingiva (sowie auf der Oberfläche von Epithelzellen, mesenchymalen und hämatopoetischen Zellen). Neben einigen noch ungeklärten Funktionen ist das Glykoprotein an der Zelladhäsion und der Bindung von Komponenten der EZM wie z.B. Fibronectin, Laminin, Kollagen und Hyaluronsäure beteiligt (Chen et al. 2006). Die Arbeitsgruppe um Hirano et al. (1997) hat herausgefunden, dass PDL-Zellen CD44 exprimieren. Sie stimulierten die Fibroblasten des humanen, gesunden PDL u.a. mit proinflammatorischen Zytokinen 
wie z.B. IL-1 $\beta$ und TNF- $\alpha$ und konnten in vitro zeigen, dass durch diese Beeinflussung der Gehalt an CD44-mRNA in den Fibroblasten erhöht ist. Unterstützt wird dieses Ergebnis durch Arbeiten von Takahashi et al. (1994) und Murakami et al. (1997), die zeigen konnten, dass unter inflammatorischen Bedingungen die Expression von Zelladhäsionsmolekülen erhöht ist. Unsere Untersuchung im FACS hat ergeben, dass die Zellen gesunden PDLs und die des parodontitisch erkrankten PDLs nur minimal CD44-positiv sind und diesbezüglich kein statistisch signifikanter Unterschied vorliegt. Auch in der real-time (RT)-PCR zeigte sich hinsichtlich der Expression im erkrankten PDL gegenüber dem gesunden keine Veränderung. Eine Erklärung dafür könnte sein, dass durch die hinzugefügte spezifische Antibiose der wesentliche inflammatorische Reiz in der Kultur ausgeschaltet wurde und sich die primär erkrankten PDL-Zellen in ihren Eigenschaften gesunden Zellen wieder annähern. Eine weitere Erklärung für diese Abweichung im Expressionsmuster könnte die Arbeit von Chen et al. (2006) liefern, die für CD44 exprimierende Zellen parodontitisch erkrankter Zähne zeigen konnten, dass diese im apikalen Bereich der Wurzel und in dem Areal um die Furkation lokalisiert sind. CD44 exprimierende Zellen gesunden PDLs finden sich nach den Angaben von Chen et al. im koronalen und apikalen Bereich und ebenfalls in der Gegend um die Furkation. Da in den Versuchen für die vorliegende Arbeit die Entnahme des PDLs gesunder und parodontitisch erkrankter Zähne zur Verringerung äußerer Einflüsse (z.B. bakterielle Kontamination aus der zervikalen oder apikalen Region) auf das mittlere Wurzeldrittel beschränkt worden ist, könnte es sein, dass eventuell nur eine minimale Anzahl an CD44-positiven PDL-Zellen für die Versuche zur Verfügung stand und auf diese Weise unsere von den bisherigen Arbeiten abweichenden Ergebnisse für CD44 zu erklären sind.

\subsection{Diskussion von CD73 (5'-Ectonucleotidase)}

Bei CD73 handelt es sich um ein Membranprotein, welches der T-Zellaktivierung dient und durch Bindung von Laminin als Zelladhäsionsmolekül fungiert (Bianchi und Spychala 2003, Resta et al. 1997, Mlodzik et al. 1995). Das Protein findet sich auf

verschiedenen Zelltypen wie z.B. Epithel- und Endothelzellen, Lymphozyten und Fibroblasten (Hashikawa et al. 2003) Die Aktivität nukleotidabbauender Ectoenzyme spielt eine wichtige Rolle in der Thromboregulation, Hämostase und Modulation 
inflammatorischer Prozesse. Die Expression von CD73 und seine enzymatische Aktivität werden durch Entzündungsmediatoren wie TNF- $\alpha, I L-1 \beta$ und $\mathrm{PGE}_{2}$ (Prostaglandin $\mathrm{E}_{2}$ ) beeinflusst. Die Aktivierung von CD73 als Antwort auf diese Stimuli führt zu einer Freisetzung von Adenosin (Hashikawa et al. 2006). Im Jahre 1994 hat Cronstein herausgefunden, dass Adenosin antiinflammatorische Eigenschaften besitzt. Unsere Untersuchungen mittels FACS haben ergeben, dass die Expression von CD73 in parodontitisch erkrankten PDL-Zellen hochsignifikant niedriger als in PDL-Zellen gesunden Gewebes ist. Dieses Ergebnis könnte man damit erklären, dass sich im Rahmen der Aufrechterhaltung der Gewebehomöostase die antiinflammatorische Wirkung von CD73 in gesundem PDL zeigt. Die Arbeitsgruppe um Zhou et al. (2008) hat das Expressionsmuster verschiedener Antigene auf Zellen von gesundem PDL hinsichtlich ihrer osteoblastären und adipozytären Induktion untersucht. CD73 wurde dabei nur in $10 \%$ der Parodontalligamentzellen entdeckt, während unsere Untersuchung im FACS für gesunde PDL-Zellen ein eindeutig positives Ergebnis erzielt. Das Ergebnis in der real-time (RT)-PCR besagt, dass der Level an CD73-mRNA in Parodontalligamentzellen parodontitisch erkrankter Zähne gegenüber dem in Zellen gesunder Zähne unverändert ist. Die Abweichung von den Feststellungen von Zhou et al. (2008) könnte man damit erklären, dass unsere Zellen während ihres Verbleibs in der Zellkultur ihr Expressionsmuster geringfügig verändert haben. Die Expression von CD73 in Zellen gesunden und parodontal erkrankten PDLs ist bisher noch nicht sehr gut untersucht worden. Das Oberflächenantigen wird oft auch in Zusammenhang mit Markern für mesenchymale Stammzellen gebracht (Huang et al. 2009, Zhou et al. 2008, Chamberlain et al. 2007), so dass hier noch ein großer Bedarf an weiteren Untersuchungen und Erkenntnissen für konkretere Aussagen zur Thematik der Stammzellen im PDL und CD73 als Marker besteht.

\subsection{Schlussfolgerungen und Ausblick}

Zusammenfassend lässt sich sagen, dass die vorliegende Arbeit eine der ersten Studien ist, welche unter Verwendung von erkrankten, infizierten PDL-Zellen in der Zellkultur mittels real-time (RT)-PCR und FACS die Genexpression zwischen chronisch entzündeten PDL-Zellen und gesunden PDL-Zellen vergleichend darlegt. Betrachtet man die Ergebnisse, so können neben gleichen Expressionsmustern im 
Expressionslevel einzelner Gene auch Unterschiede festgestellt werden. Diese Unterschiede in der Expression zwischen dem parodontal erkrankten und dem gesunden Gewebe lassen sich u.a. auf die Anwesenheit spezifischer Bakterien mit ihren Metaboliten zurückführen. Bisher konnte mit der in der Zellkultur konventionell verabreichten Antibiose nur eine unzureichend reduzierte Kontamination erzielt werden. Nun, durch die spezifische, wirksame Antibiose erfolgt allerdings die vollständige Elimination der Mikroorganismen und somit entfällt auch der inflammatorische Reiz vollständig. Ein Halten des inflammatorischen Reizes mit seinen Metaboliten und Toxinen könnte noch detaillierter über die bestehenden Unterschiede hinsichtlich der Genexpression Aufschluss geben. Hierzu käme beispielsweise eine teilweise Keim-Elimination durch eine diffizilere Antibiose in Betracht. Eine weitere Möglichkeit wäre eventuell, in einem Zwei-Kammer-System der Zellkultur parodontopathogene Keime und PDL-Zellen parallel zu kultivieren. Ein Überwuchern durch die Bakterien könnte durch eine Membran verhindert werden, welche allerdings wiederum die Metabolite und Toxine ins Medium der Zellen diffundieren lässt und so möglicherweise zur Konservierung der inflammatorisch geprägten Charakteristika der Zellen beiträgt. Diese Zellen könnten unter dem fortwährenden Einfluss der parodontopathogenen Infektion durch Metabolite und Toxine expandiert werden. Die Erkenntnisse dieser Arbeit liefern eine wichtige Grundlage für die Entwicklung eines in-vitro-Modells, mit dem die primäre Kultur von Zellen parodontal erkrankter Patienten ermöglicht wird. Anhand dieser und zukünftiger Daten wird ein Einblick verschafft, welche Gene und Komponenten an dem Entzündungsgeschehen beteiligt sein könnten, und es bildet die Grundlage zum besseren Verständnis der pathophysiologischen Vorgänge. Die komplexen Zusammenhänge, die sich während der Entzündung vollziehen, können mithilfe dieser Studien genauer aufgezeigt werden. So können anhand der vergleichenden Charakterisierungen von Zellen aus erkrankten Parodontien relativ zu gesunden Zellen weitere Ergebnisse gewonnen werden, aus denen möglicherweise (regenerative) Therapieansätze abgeleitet werden können und das klinische Therapiespektrum erweitert werden kann. 


\section{Zusammenfassung}

Neben der Karies ist die chronische Parodontitis die häufigste Ursache für den Zahnverlust. Die Entstehung und die Progression dieser entzündlichen Parodontalerkrankung sind primär durch pathogene Mikroorganismen bedingt. Diese Dissertation beschäftigt sich mit der Etablierung einer Zellkultur aus parodontal erkrankten PDL-Zellen unter Entwicklung einer spezifischen Antibiose zur Kultivierung und einer sich daran anschließenden vergleichenden Charakterisierung der Genexpressionsmuster von gesunden und erkrankten PDL-Zellen. Die Analyse wird unter Verwendung der Methoden des FACS und der real-time (RT)-PCR durchgeführt. Die Ergebnisse zeigen in der real-time (RT)-PCR eine Herunterregulation von Kollagen Typ I und Runx2 im Vergleich zu gesunden PDLZellen. Eine unveränderte Expression stellt sich für CD13 und CD73 als Faktoren, welche die Immunantwort modulieren, und für CD44 und CD29 als Adhäsionsmoleküle dar. Die statistische Auswertung der FACS-Ergebnisse ergibt, dass zwischen gesunden und parodontal erkrankten PDL-Zellen für Kollagen Typ I und CD73 signifikante Unterschiede in der Expression bestehen; die Expression ist jeweils im erkrankten Gewebe niedriger. Im Rahmen der Charakterisierungsstudien von erkrankten im Vergleich zu gesunden PDL-Zellen konnten sich einige Unterschiede in den jeweiligen Expressionsmustern darstellen lassen, jedoch nicht so deutlich wie in vorangegangenen ex-vivo-Microarray-Studien unserer Arbeitsgruppe. Hierfür könnte die Angleichung der primär erkrankten PDL-Zellen aufgrund des in Kultur fehlenden inflammatorischen Reizes verantwortlich sein. Demnach tragen die im Rahmen dieser Arbeit gewonnenen Erkenntnisse bei zu der Entwicklung einer detaillierten „Simulation“ der chronischen Parodontitis in vitro, z.B. in Form eines Zwei-Kammer-Modells (mit paralleler Bakterien-/Zellen-Kultur unter Aufrechterhaltung entzündungsähnlicher Konditionen). Die Ergebnisse aus dem FACS und der real-time (RT)-PCR verbessern das Verständnis der pathophysiologischen Vorgänge der chronischen Parodontitis und stellen eine weitere Grundlage für die nachfolgende Entwicklung von Therapieansätzen und die Erweiterung des klinischen Therapiespektrums dar. 


\section{Literaturverzeichnis}

Aktories K, Förstermann U, Hofmann F, Starke K: Allgemeine und spezielle Pharmakologie und Toxikologie. 9. Auflage; Elsevier $\mathrm{GmbH}$, Urban und Fischer Verlag, München 2005

Banerjee C, Javed A, Choi JY, Green J, Rosen V, Wijnen AJ van, Stein JL, Lian JB, Stein GS (2001): Differential regulation of the two principal Runx2/Cbfa1 N-terminal isoforms in response to bone morphogenetic protein-2 during development of the osteoblast phenotype. Endocrinology 142: 4026-4039

Benatti BB, Silvério KG, Casati MZ, Sallum EA, Nociti FH Jr (2008): Influence of aging on biological properties of periodontal ligament cells. Connect Tissue Res $\underline{49}$ : 6, 401-408

Berkovitz BK (2004): Periodontal ligament: structural and clinical correlates. Dent Update $\underline{31}: 1,46-50,52,54$

Bianchi V, Spychala J (2003): Mammalian 5'-nucleotidases. J Biol Chem 278: 46195- 46198.

Birn H (1966): The vascular supply of the periodontal membrane. An investigation of the number and size of perforations in the alveolar wall. J Periodontal Res 1: 51-68

Brakebusch C, Hirsch E, Potocnik A, Fässler R (1997): Genetic analysis of $\beta 1$ integrin function: confirmed, new and revised roles for a crucial family of cell adhesion molecules. J Cell Sci 110: 2895-2904

Brietze R: Vergleichende Gen-Expressionsprofile der an der Entzündungsreaktion beteiligten Mediatoren von gesunden und erkrankten Parodontalligamentzellen in vivo. Med. Diss. Göttingen 2007 
Bustin SA, Nolan T (2004): Pitfalls of Quantitative Real-Time Reverse-Transcription Polymerase Chain Reaction. J Biomol Tech 15: 155-166

Butler WT, Birkedal-Hansen H, Beegle WF, Taylor RE, Chung E (1975): Proteins of the periodontium. Identification of collagens with the [alpha1(I)]2alpha2 and [alpha1(III)]3 structures in bovine periodontal ligament. J Biol Chem 250: 23, 89078912

Camilleri S, McDonald F (2006): Runx2 and dental development. Eur J Oral Sci 114: 361-373

Chamberlain G, Fox J, Ashton B, Middleton J (2007): Concise review: Mesenchymal stem cells: Their phenotype, differentiation capacity, immunological features, and potential for homing. Stem Cells $\underline{25}$ : 2739-2749

Chen SC, Marino V, Gronthos S, Bartold PM (2006): Location of putative stem cells in human periodontal ligament. J Periodont Res 41: 547-553

Cimasoni G (1983): Crevicular fluid updated. Monogr Oral Sci 12: III-VII, 1-152

Cionca N, Giannopoulou C, Ugolotti G, Mombelli A (2010): Microbiologic testing and outcomes of full-mouth scaling and root planing with or without amoxicillin/metronidazole in chronic periodontitis. J Periodontol 81: 1, 15-23

Cronstein BN (1994): Adenosine, an endogenous anti-inflammatory agent. J Appl Physiol 76: 5-13

\section{Datenbank des National Center for Biotechnology Information (NCBI) 2007:} www.ncbi.nlm.nih.gov

Dennison DK, Van Dyke TE (1997): The acute inflammatory response and the role of phagocytic cells in periodontal health and disease. Periodontol 2000 14: 54-78 
Deschner J, Arnold B, Kage A, Zimmermann B, Kanitz V, Bernimoulin JP (2000): Suppression of interleukin-10 release from human periodontal ligament cells by interleukin-1 beta in vitro. Arch Oral Biol 45: 2, 179-183

Dheda K, Huggett JF, Bustin SA, Johnson MA, Rook G, Zumla A (2004): Validation of housekeeping genes for normalizing RNA expression in real-time PCR. BioTechniques $\underline{37}$ : 112-119

Drissi H, Pouliot A, Koolloos C, Stein JL, Lian JB, Stein GS, van Wijnen A J (2002): 1,25-(OH)2-vitamin D3 suppresses the bone-related Runx2/Cbfa1 gene promoter. Exp Cell Res 274: 2, 323-333

Duan Y, Fisher E, Malamud D, Golub E, Demuth DR (1994): Calcium-binding properties of SSP-5, the Streptococcus gordonii M5 receptor for salivary agglutinin. Infect Immun 62: 12, 5220-5226

Ducy P, Zhang R, Geoffroy V, Ridall AL, Karsenty G (1997): Osf2/Cbfa1: a transcriptional activator of osteoblast differentiation. Cell $\underline{89}$ : 747-754

Eckmann L, Kagnoff MF, Falco MT (1994): Colonic epithelial cell lines as a source of interleukin-8: stimulation by inflammatory cytokines and bacterial lipopolysaccharide. Immunology 82: 4, 505

Eley BM, Harrison JD (1975): Intracellular collagen fibrils in the periodontal ligament of man. J Periodontal Res 10: 3, 168-170

Everts V, Niehof A, Jansen D, Beertsen W (1998): Type VI collagen is associated with microfibrils and oxytalan fibers in the extracellular matrix of periodontium mesenterium and periosteum. J Periodontal Res 33: 2, 118-125

Feres M, Haffajee AD, Allard K, Som S, Socransky SS (2001): Change in subgingival microbial profiles in adult periodontitis subjects receiving either systemically-administered amoxicillin or metronidazole. J Clin Periodontol 28: 7, 597609 
Galindo M, Pratap J, Young DW, Hovhannisyan H, Im HJ, Choi JY, Lian JB, Stein GS, van Wijnen AJ (2005): The bone-specific expression of Runx2 oscillates during the cell cycle to support a G1-related antiproliferative function in osteoblasts. J Biol Chem 280: 21, 20274-20285

Gay IC, Chen S, MacDougall M (2007): Isolation and characterization of multipotent human periodontal ligament stem cells. Orthod Craniofacial Res 10: 149-160

Gemmell E, Walsh LJ, Savage NW, Seymour GJ (1994): Adhesion molecule expression in chronic inflammatory periodontal disease tissue. J Periodont Res $\underline{29}$ : 46-53

Gemmell E, Marshall RI, Seymour GJ (1997): Cytokines and prostaglandins in immune homeostasis and tissue destruction in periodontal disease. Periodontol 2000 14: 112-143

Giancotti FG, Ruoslahti E (1999): Integrin signaling. Science 285: 5430, 1028-1032

Gilsbach R, Kouta M, Bonisch H, Bruss M (2006): Comparison of in vitro and in vivo reference genes for internal standardization of real-time PCR data. Biotechniques $\underline{40}$ : $2,173-177$

Goené RJ, Winkel EG, Abbas F, Rodenburg JP, van Winkelhoff AJ, de Graaff J (1990): Microbiology in diagnosis and treatment of severe periodontitis. A report of four cases. J Periodontol 61: 1, 61-64

Graaff J de, van Winkelhoff AJ, Goené RJ (1989) The role of Actinobacillus actinomycetemcomitans in periodontal disease. Infektion 17: 4, 269-271

Granstrom G, Nilsson LP (1987): Experimental mandibular fracture: studies on bone repair and remodellation. Scand J Plast Recontr Surg Hand Surg 21: 2, 159-165 
Haffajee AD, Torresyap G, Socransky SS (2007): Clinical changes following four different periodontal therapies for the treatment of chronic periodontitis: 1-year results. J Clin Periodontol 34: 243-253

Hashikawa T, Takedachi M, Terakura M, Saho S, Yamada S, Thompson LF, Shimabukuro Y, Murakami S (2003): Involvement of CD73 (ecto-5'-nucleotidase) in Adenosine Generation by Human Gingival Fibroblasts. J Dent Res $\underline{82}$ : 11, 888-892

Hashikawa T, Takedachi M, Terakura M, Yamada S, Thompson LF, Shimabukuro Y, Murakami S (2006): Activation of Adenosin Receptor on Gingival Fibroblasts. J Dent Res 85: 8, 739-744

Hertwig $O$ (1874): Über das Zahnsystem der Amphibien und seine Bedeutung für die Genese des Skelettes der Mundhöhle. Eine vergleichende anatomische, entwicklungsgeschichtliche Untersuchung. Arch Mikr Anat Suppl 1: 205

Hintermann E, Quaranta V (2004): Epithelial cell motility on laminin-5: regulation by matrix assembly, proteolysis, integrins and erbB receptors. Matrix Biol 23: 2, 75-85

Hirano F, Hirano H, Hino E, Takayama S, Saito K, Kusumoto Y, Shimabukuro Y, Murakami S, Okada H (1997): CD44 isoform expression in periodontal tissues: celltype specific regulation of alternative splicing. J Periodont Res $\underline{32}$ : 634-645

Holodniy M: Effects of Collection, Processing, and Storage on RNA Detection and Quantification. Kochanowski B, Reischl U in "Quantitative PCR Protocols“. Humana Press 1999, Totowa

Huang GT, Gronthos S, Shi S (2009): Mesenchymal stem cells derived from dental tissues vs. those from other sources: their biology and role in regenerative medicine. J Dent Res 88: 9, 792-806

International Workshop for a Classification of Periodontal Diseases and Conditions (1999): Papers. Oak Brook, Illinois, October 30-November 2, 1999. Ann Periodontol 4 : 1, i, 1-112 
Itaya T, Kagami H, Okada K, Yamawaki A, Narita Y, Inoue M, Sumita Y, Ueda M (2009): Characteristic changes of periodontal ligament-derived cells during passage. J Periodont Res 44: 425-433

James JA, Sayers NM, Drucker DB, Hull PS (1999): Effects of tobacco products on the attachment and growth of periodontal ligament fibroblasts. J Periodontol $\underline{70}$ : 5, 518-525

Jonas IE, Riede UN (1980): Reaction of oxytalan fibers in human periodontium to mechanical stress. A combined histochemical and morphometric analysis. J Histochem Cytochem 28: 3, 211-216

Kanayama N, Kajiwara Y, Goto J, El Maradny E, Maehara K, Andou K, Terao T (1995): Inactivation of interleukin-8 by aminopeptidase N (CD13). J Leukoc Biol $\underline{57}$ : $129-134$

Kern B, Shen J, Starbuck M, Karsenty G (2001): Cbfa1 contributes to the osteoblastspecific expression of type I collagen genes. J Biol Chem 276: 10, 7101-7107

Khoury AE, Lam K, Ellis B, Costerton J W (1992): Prevention and control of bacterial infections associated with medical devices. Asaio J 38: 3, M174-178

Kleber BM: Parodontologie-Kompendium für Studierende und Zahnärzte. Deutscher Ärzteverlag, Köln 1998

Komori T (2002): A fundamental transcription factor for bone and cartilage. Biochem Biophys Res Commun 276: 3, 813-816

Kornman KS, Page RC, Tonetti MS (1997): The host response to the microbial challenge in periodontitis: assembling the players. Periodontol 2000 14: 33-53

Kunii R, Nemoto E, Kanaya S, Tsubahara T, Shimauchi H (2005): Expression of CD13/aminopeptidase $\mathrm{N}$ on human gingival fibroblasts and up-regulation upon stimulation with interleukin-4 and interleukin-13. J Periodont Res $\underline{40}$ : 138-146 
Kuru L, Parkar MH, Griffiths GS, Newman HN, Olsen I (1998): Flow cytometry analysis of gingival and periodontal ligament cells. J Dent Res $\underline{77}$ : 4, 555-564

Lallier TE, Spencer A (2007): Use of microarrays to find novel regulators of periodontal ligament fibroblast differentiation. Cell Tissue Res $\underline{327}$ : 93-109

Larjava H, Sandberg M, Vuorio E (1989): Altered distribution of type I collagen mRNA in periodontal disease. J Periodontal Res $\underline{24}$ : 3, 171-177

Limeback HF, Sodek J (1979): Procollagen synthesis and processing in periodontal ligament in vivo and in vitro. A comparative study using slab-gel fluorography. Eur $\mathrm{J}$ Biochem 100: 2, 541-550

Lindhe J, Haffajee AD, Socransky SS (1983): Progression of periodontal disease in adult subjects in the absence of periodontal therapy. J Clin Periodontol 10: 4, 433442

Lindl T, Bauer J: Zell- und Gewebekultur. 5. Auflage; Spektrum Akademischer Verlag $\mathrm{GmbH}$, Heidelberg 2002

Liu K, Meng H, Lu R, Xu L, Zhang L, Chen Z, Shi D, Feng X, Tang X (2010): Initial periodontal therapy reduced systemic and local 25-hydroxy vitamin $D_{3}$ and interleukin-1 $\beta$ in patients with aggressive periodontitis. J Periodontol 81: 260-266

Loe H, Morrison E (1986): Periodontal health and disease in young people: screening for priority care. Int Dent J $\underline{36}$ : 3, 162-167

Loesche WJ, Syed SA, Morrison EC, Laughon B, Grossman NS (1981): Treatment of periodontal infections due to anaerobic bacteria with short-term treatment with metronidazole. J Clin Periodontol 8: 1, 29-44

Loesche WJ, Giordano JR, Hujoel P, Schwarcz J, Smith BA (1992): Metronidazole in periodontitis: reduced need for surgery. J Clin Periodontol 19: 2, 103-112 
Look AT, Ashmun RA, Shapiro LH, Peiper SC (1989): Human Myeloid Plasma Membrane Glycoprotein CD13 (gp150) Is Identical to Aminopeptidase N. J Clin Invest 83: 1299-1307

Loppnow H, Brade H, Durrbaum I, Dinarello CA, Kusumoto S, Rietschel ET, Flad HD (1989): IL-1 induction-capacity of defined lipopolysaccharide partial structures. J Immunol 142: 9, 3229-3238

Luan Y, Xu W (2007): The structure and main functions of aminopeptidase N. Curr Med Chem 14: 6, 639-647

Lukic A, Vojvodic D, Majstorovic I, Colic M (2006): Production of interleukin-8 in vitro by mononuclear cells isolated from human periapical lesions. Oral Microbiol Immunol 21: $5,296-300$

Meisel P, Kohlmann T, Kocher T (2007): Association of height with inflammation and periodontitis: the Study of Health in Pomerania. J Clin Periodontol 34: 5, 390-396

Melcher AH, Chan J (1981): Phagocytosis and digestion of collagen by gingival fibroblasts in vivo: a study of serial sections. J Ultrastruct Res $\underline{77}: 1,1-36$

Micheelis W, Schiffner U: Vierte Deutsche Mundgesundheitsstudie (DMS IV). Deutscher Zahnärzteverlag, Band 31, Köln 2006

Miyata Y, Takeda H, Kitano S, Hanazawa S (1997): Porphyromonas gingivalis lipopolysaccharide-stimulated bone resorption via CD14 is inhibited by broadspectrum antibiotics. Infect Immun 65: 9, 3513-3519

Mlodzik K, Loffing J, Le Hir M, Kaissling B (1995): Ecto-5'-nucleotidase is expressed by pericytes and fibroblasts in the rat heart. Histochem Cell Biol 103: 227-236

Molnár B, Kádár K, Király M, Porcsalmy B, Somogyi E, Hermann P, Grimm WD, Gera I, Varga G (2008): Isolation, cultivation and characterisation of stem cells in human periodontal ligament. Fogorv Sz 101: 4, 155-161 
Müller H: Parodontologie. Thieme Verlag, Stuttgart 2001

Murakami S, Shimabukuro Y, Saho T, Hino E, Kasai D, Hashikawa T, Hirano H, Okada H (1997): Immunoregulatory roles of adhesive interactions between lymphocytes and gingival fibroblasts. J Periodont Res $\underline{32}$ : 110-114

Nagatomo K, Komaki M, Sekiya I, Sakaguchi Y, Noguchi K, Oda S, Muneta T, Ishikawa I (2006): Stem cell properties of human periodontal ligament cells. J Periodont Res 41: 303-310

Nanci A, Somerman MJ: Periodontium; in: Ten Cate`s Oral Biology: Development, Structure, and Function, 4. überarbeitete Auflage; hrsg. v. Nanci A; Mosby Verlag, St. Louis (MO), 1994

Newman MG, Williams RC, Crawford A, Mangianella A, Socransky SS (1973): Predominant cultivable microbiotia of periodontitis and periodontosis. J Dent Res $\underline{52}$ : 290

Okazaki K, Uzuka M, Morikawa F, Toda K, Seiji M (1976): Transfer mechanism of melanosomes in epidermal cell culture. J Invest Dermatol 67: 4, 541-547

Page RC, Schroeder HE (1976): Pathogenesis of inflammatory periodontal disease. A summary of current work. Lab Invest 43: 235-249

Page RC, Offenbacher S, Schroeder HE, Seymour GJ, Kornman KS (1997): Advances in the pathogenesis of periodontitis: summary of developments, clinical implications and future directions. Periodontol 2000 14: 216-248

Pfaffl MW (2001): A new mathematical model for relative quantification in real-time RT-PCR. Nucleic Acids Res 29: 9, 2002-2007

Pindborg JJ: Atlas der Mundschleimhauterkrankungen. Deutscher Ärzteverlag, Köln 1987 
Preshaw PM, Seymour RA, Heasman A (2004): Current concepts in periodontal pathogenesis. Dent Update $\underline{31}$ : 10, 570-572, 574-578

Proceedings of the World Workshop in Clinical Periodontics (1989): Princeton, New Jersey, July 23-27, 1989. The American Academy of Periodontology, Chicago, I/23-I/24

Resta R, Hooker SW, Laurent AB, Jamshedur Rahman SM, Franklin M, Knudsen TB, Nadon NL, Thompson LF (1997): Insights into thymic purine metabolism and adenosine deaminase deficiency revealed by transgenic mice overexpressing ecto5'-nucleotidase. J Clin Invest 99: 676-683

Reynolds JJ, Meikle MC (1997): Mechanisms of connective tissue matrix destruction in periodontitis. Periodontol 2000 14: 144-157

Schroeder HE: Orale Strukturbiologie. 5. Auflage; Thieme Verlag, Stuttgart 2000

Schroeder HE, Theilade J (1966): Electron microscopy of normal human gingival epithelium. J Periodontal Res 1: 2, 95-119

Schroeder TM, Jensen ED, Westendorf JJ (2005): Runx2: A master organizer of gene transcription in developing and maturing osteoblasts. Birth Defects Res C Embryo Today $\underline{75}$ : 3, 213-225

Schuessler CF, Fairchild JM, Stransky IM (1945): Penicillin in the treatment of Vincent`s infection. J Am Dent Assoc $\underline{32}$

Sellars MJ, Vuocolo T, Leeton LA, Coman GJ, Degnan BM, Preston NP (2007): Real-time RT-PCR quantification of Kuruma shrimp transcripts: A comparison of relative and absolute quantification procedures. J Biotechnol 129: 3, 391-399

Seo BM, Miura M, Gronthos S, Bartold PM, Batouli S, Brahim J, Young M, Robey PG, Wang CY, Shi S (2004): Investigation of multipotent postnatal stem cells from human periodontal ligament. Lancet $2004 \underline{364}$, 149-155 
Shi S, Bartold PM, Miura M, Seo BM, Robey PG, Gronthos S (2005): The efficacy of mesenchymal stem cells to regenerate and repair dental structures. Orthod Craniofacial Res ㅁ: 191-199

Sims MR (1975): Oxytalan-vascular relationships observed in histologic examination of the periodontal ligaments of man and mouse. Arch Oral Biol 20: 11, 627-639

Siqueira JF Jr, Rôcas IN, Alves FR, Silva MG (2009): Bacteria in the apical root canal of teeth with primary apical periodontitis. Oral Surg Oral Med Oral Pathol Oral Radiol Endod 107: 5, 721-726

Skougaard M (1965): Turnover of the gingival epithelium in marmosets. Acta Odontol Scand 23: 6, 623-643

Strock A (1944): Penicillin in the treatment of Vincent's infection in Naval recruits. Am J Surg 50: 23-29

Sullivan CB, Diggle MA, Clarke SC (2005): Multilocus sequence typing: Data analysis in clinical microbiology and public health. Mol Biotechnol 29: 3, 245-254

Szydlik S: Vergleichende Genexpressionsanalysen von Komponenten der extrazellulären Matrix im parodontal gesunden Gewebe und bei der chronischen Parodontitis in vivo. Med. Diss. Göttingen 2009

Takahashi K, Takigawa M, Takashiba S, Nagai A, Miyamoto M, Kurihara H, Murayama $Y$ (1994): Role of cytokine in the induction of adhesion molecules on cultured human gingival fibroblasts. J Periodontol $\underline{65}$ : 230-235

Tasman F, Ataç A, Er N, Dagdeviren A, Kendir B (2001): Expression of $\beta 1$ integrins in human dental pulp in vivo: a comparative immunohistochemical study on healthy and chronic marginal periodontitis samples. Int Endod J 34: 11-15 
Temeles DS, McGrath HE, Kittler EL, Shadduck RK, Kister VK, Crittenden RB, Turner BL, Quesenberry PJ (1993): Cytokine expression from bone marrow derived macrophages. Exp Hematol 21: 2, 388-393

Ten Cate AR (1972): Morphological studies of fibrocytes in connective tissue undergoing rapid remodelling. J Anat 112: Pt 3, 401-414

Ten Cate AR, Deporter DA (1974): The role of the fibroblast in collagen turnover in the functioning periodontal ligament of the mouse. Arch Oral Biol 19: 4, 339-340

Ten Cate AR, Deporter DA, Freeman E (1976): The role of the fibroblast in the remodeling of the periodontal ligament during physiologic tooth movement. Am $\mathrm{J}$ Orthod 69: 155-168

Tonetti MS, Freiburghaus K, Lang NP, Bickel M (1993): Detection of interleukin-8 and matrix metalloproteinases transcripts in healthy and diseased gingival biopsies by RNA/PCR. J Periodontal Res 28: 6 Pt 2, 511-513

Trubiani O, Di Primio R, Traini T, Pizzicannella J, Scarano A, Piattelli A, Caputi S (2005): Morphological and cytofluorimetric analysis of adult mesenchymal stem cells expanded ex vivo from periodontal ligament. Int J Immunopathol Pharmacol 18: 2, 213-221

Uitto VJ, Larjava H, Peltonen J, Brunette DM (1992): Expression of fibronectin and integrins in cultured periodontal ligament epithelial cells. J Dent Res 71: 5, 12031211

Van Heeckeren AM, Rikihisa Y, Park J, Fertel R (1993): Tumor necrosis factor alpha, interleukin-1 alpha, interleukin-6, and prostaglandin E2 production in murine peritoneal macrophages infected with Ehrlichia risticii. Infect Immun 61: 10, 43334337 
Washio K, Iwata T, Mizutani M, Ando T, Yamato M, Okano T, Ishikawa I (2010): Assessment of cell sheets derived from human periodontal ligament cells: a preclinical study. Cell Tissue Res, im Druck

Whittaker CJ, Klier CM, Kolenbrander PE (1996): Mechanisms of adhesion by oral bacteria. Annu Rev Microbiol 50: 513-552

Williams RC (2008): Understanding and managing periodontal diseases: a notable past, a promising future. J Periodontol $\underline{79}: 8$ (Suppl.)

Winkelhoff AJ van, Rodenburg JP, Goené RJ, Abbas F, Winkel EG, de Graaff J (1989): Metronidazole plus amoxycillin in the treatment of Actinobacillus actinomycetemcomitans associated periodontitis. J Clin Periodontol 16: 2, 128-131

Wolf HF, Rateitschak KH, Rateitschak EM: Parodontologie. 3. Auflage; Thieme Verlag, Stuttgart 2003

Xu J, Clark RA (1996): Extracellular matrix alters PDGF regulation of fibroblast integrins. J Cell Biol 132: 239-249

Zhou Y, Hutmacher DW, Sae-Lim V, Zhou Z, Woodruff M, Meng Lim T (2008): Osteogenic and adipogenic induction potential of human periodontal cells. J Periodontol 79: 525-534

Zhu Y, Su Y, Cheng T, Chung L W, Shi C (2009): ß2-Microglobulin as a potential factor for the expansion of mesenchymal stem cells. Biotechnol Lett 31: 1361-1365 


\section{Danksagungen}

Besonderer Dank gilt Herrn Prof. Dr. N. Miosge für die Überlassung des Themas und für die geduldige Korrektur der Arbeit. Mit der Durchführung der vorliegenden Dissertation ermöglichte er mir zudem einen Einblick in das wissenschaftliche Arbeiten.

Ein herzliches Dankeschön gebührt Herrn Dr. M. Rödiger für die Übernahme der Betreuung, im Rahmen derer er mir engagiert mit Rat und Tat verlässlich und kompetent zur Seite stand.

Frau B. Sadowski sei für ihre Hilfsbereitschaft und ihre Geduld bei der Einarbeitung in die Zellkultivierung gedankt. Auf ihre Unterstützung bei allen meine Arbeit im Labor betreffenden Fragen konnte ich mich stets verlassen.

Ein großer Dank geht an die wissenschaftlichen Mitarbeiter der Abteilung für Medizinische Statistik der Universitätsmedizin Göttingen, David Ellenberger und Simon Schneider, für die schnelle und kompetente Hilfe bei der statistischen Auswertung meiner Daten. 


\section{Curriculum Vitae}

Anna Maria Entorf

Fridtjof-Nansen-Weg 13

37085 Göttingen

Am 27. Juni 1982 wurde ich als jüngstes Kind von Udo Entorf und Helga EntorfAlbrecht in Wittingen, Landkreis Gifhorn, geboren. Mein Vater war als Rektor einer Realschule tätig und meine Mutter ist Lehrerin. Ich besuchte von 1989 bis 1993 die Grundschule in Wittingen und im Anschluss daran für zwei Jahre die dortige Orientierungsstufe. Ab 1995 besuchte ich mit Beginn der 7. Klasse das Gymnasium Hankensbüttel, wo ich am 10. Juni 2002 mit dem Abitur die allgemeine Hochschulreife erwarb.

Zum Wintersemester 2002/2003 nahm ich an der Georg-August-Universität Göttingen für ein Semester das Studium der Sozialwissenschaften auf und wechselte zum Sommersemester 2003 zum Studium der Zahnmedizin. Am 26. Februar 2004 legte ich dort die naturwissenschaftliche Vorprüfung ab und am 15. September 2005 bestand ich die zahnärztliche Vorprüfung. Am 03. Juni 2009 schloss ich das Studium mit der zahnärztlichen Prüfung ab und erhielt die Approbation.

Seit dem 15. September 2009 arbeite ich als Assistenzzahnärztin im Zentrum ZMK der Georg-August-Universität Göttingen in der Abteilung Prothetik. 